\title{
Assessment of multifunctional landscapes dynamics in the mountainous basin of the Mo River (Togo, West Africa)
}

\author{
DIWEDIGA Badabate ${ }^{1,3}$, AGODZO Sampson², WALA Kperkouma ${ }^{3}$, \\ LE Quang Bao ${ }^{4}$
}

1. WASCAL Graduate Research Program in Climate Change and Land Use; Department of Civil Engineering, Kwame Nkrumah University of Science and Technology, Kumasi, Ghana;

2. Department of Agricultural Engineering, Kwame Nkrumah University of Science and Technology, Kumasi, Ghana;

3. Laboratory of Botany and Plant Ecology; University of Lomé, Togo;

4. CGIAR Research Program on Dryland Systems (CRP-DS), International Centre for Agricultural Research in Dry Areas (ICARDA), Amman 11195, Jordan

\begin{abstract}
In this study, historical landscape dynamics were investigated to (i) map the land use/cover types for the years 1972, 1987, 2000 and 2014; (ii) determine the types and processes of landscape dynamics; and (iii) assess the landscape fragmentation and habitat loss over time. Supervised classification of multi-temporal Landsat images was used through a pixel-based approach. Post-classification methods included systematic and random change detection, trajectories analysis and landscape fragmentation assessment. The overall accuracies (and Kappa statistics) were of $68.86 \%(0.63), 91.32 \%(0.79), 90.66 \%(0.88)$ and $91.88 \%(0.89)$ for 1972, 1987, 2000 and 2014, respectively. The spatio-temporal analyses indicated that forests, woodlands and savannahs dominated the landscapes during the four dates, though constant areal decreases were observed. The most important dynamic process was the decline of woodlands with an average annual net loss rate of $-2 \%$. Meanwhile, the most important land transformation occurred during the transition 2000-2014, due to anthropogenic pressures. Though the most important loss of vegetation greenness occurred in the unprotected areas, the overall analyses of change indicated a declining trend of land cover quality and an increasing landscape fragmentation. Sustainable conservation strategies should be promoted while focusing restoration attention on degraded lands and fragmented ecosystems in order to support rural livelihood and biodiversity conservation.
\end{abstract}

Keywords: land cover dynamics; spatio-temporal patterns; swap change; landscape fragmentation; protected areas; Mo River Basin, Togo

\section{Introduction}

Controlling the dynamics of land resource for global change mitigation remains ever of greater

Received: 2016-01-27 Accepted: 2016-06-28

Author: Diwediga Badabate, $\mathrm{PhD}$, specialized in integrated soil-landscape assessment and modeling.

E-mail: diwedigaba@gmail.com; diwedigaba@yahoo.fr 
importance at global scale as well as national and local levels. Estimates indicated that forest areas have decreased of about $3.1 \%$ over the past 25 years and the largest deforestation and forest degradation occur in tropical areas of America and Africa (FAO, 2015). Similarly, the same report highlighted that between 2010 and 2015, the annual gain of forestlands was far below to the extent of loss, resulting in a net annual loss of 3.3 million ha of forests per annum. Regardless of the scale, processes inducing the loss of natural vegetation cover, forest fragmentation and associated land use/cover changes (LUCC) occur continuously, leading to land cover quality decline and degradation. From the perspective of the Millennium Ecosystem Assessment (MEA, 2005), the degradation of vegetation functions and services (e.g. forest degradation, habitat fragmentation), and the loss of natural land productivity (e.g. deforestation) are two major manifestations of the phenomenon of land degradation. From this view, long-term, permanent and regular monitoring of the landscape dynamics is regarded as an essential step for a real understanding of the change drivers and for modelling mindsets towards mitigation of land degradation and achievement of sustainability (Houet et al., 2010; Fan et al., 2013).

Spatio-temporal changes of landscapes are continuous processes fully maintained by both natural and human-related drivers. Human imprints on terrestrial ecosystems are of large extent (Ellis, 2011; Gaia, 2011) and of major environmental concerns related to habitat fragmentation, decline of land and ecosystem services (ESS), biodiversity loss, livelihood decrease and climate instability (Balthazar et al., 2015; Schleuning et al., 2011). The drivers of these forest fragmentation and deforestation are mainly human-induced such as agriculture, large-scale forest harvest, and small-scale forest disturbances (Lambin et al., 2003; Damnyag et al., 2013; Specht et al., 2015). The increasing demand for agricultural lands and forest products induced the reduction of land conservation capacities and the ESS provision, even in protected areas that have such devoted conservation role (Castro et al., 2015; Vedeld et a1., 2012; Traoré et al., 2012; Folega et al., 2014b; Damnyag et al., 2013). In this "Anthropocene" epoch, the complexity of interactions between human and environmental systems and subsequent effects have raised much more awareness (Ellis, 2013; Ellis et al., 2013).

A recent growing concern in scientific communities is how much land has changed and how this dynamic is going to affect the future of land resources. Therefore, spatial patterns of land degradation, its causal factors and potential impacts have been investigated through various approaches, scales and dimensions (Zheng et al., 2014; Kim et al., 2014; He et al., 2014; Vu et al., 2014; Le et al., 2012). Geographic information systems (GIS) and remote sensing (RS) approaches have evolved increasingly to support monitoring landscape dynamics at different scales for better planning and management (Kennedy et al., 2009; Griffiths et al., 2012; Portillo-Quintero et al., 2012). These satellite archives such as Landsat data have brought new insights into the approaches of understanding of LUCC, and monitoring deforestation and forest degradation (DFD) processes. The successes of the application of GIS and RS in the assessment of landscape dynamics remain in the availability of earth observation data as well as the multitude of methods for land cover mapping and degradation assessment (Zhou et al., 2012; Kim et al., 2013; Gounaridis et al., 2014; He et al., 2014; Kim et al., 2014; Zheng et al., 2014; Zhou et al., 2014a). These data and methods offer great potential to cover various spatio-temporal scales of analyses and monitoring of 
LUCC (Farooq, 2012; Rogan and Chen, 2004). Change detection analyses also brought significant contribution to the understanding of the processes involved in landscape dynamics. Furthermore, habitat quality assessment and landscape fragmentation analyses emerged from the combination of these tools and data to provide more appraisal to landscape dynamics and impacts on ecosystems. Landscape metrics are ecological indicators used to quantify the composition and spatial configuration of landscapes (Uuemaa et al., 2013; Mander and Uuemaa, 2010; Peng et al., 2010). Thus, as an essential approach in quantifying landscape spatial patterns with distinct ecological implications, landscape metrics help in the analysis of LUCC patterns and related ecological effects (Walz, 2011; Uuemaa et al., 2013). Thus, the integration of multi-temporal satellite data in combination with GIS and field data showed great insights in addressing landscape change and degradation at various scales.

In Togo, several recent studies have been undertaken using GIS and RS to assess and monitor the changes in land resources at national and local scales (Folega et al., 2014b; Folega et al., 2014a; Badjana et al., 2014; Folega et al., 2011; Folega et al., 2015). Human activities especially agricultural expansion, illegal tree logging and incursions in PA as well as settlement enlargement in rural and semi-urban areas have been identified as responsible for most of the changes (Fontodji et al., 2011; Dourma et al., 2009; Kokou et al., 2009). These studies have shown that current trends of land resources do not favor the functional services of the different ecosystems. Therefore, continual and complementary studies are encouraged to deepen the knowledge on the processes and determinants of LUCC for supporting integrated land management. Especially, the monitoring of the processes involved in land dynamics in rural mountainous areas of the Mo River Basin have not yet gained enough attention although they are the location of numerous social and ecological interactions (Dourma et al., 2009). Therefore, this study focused on the analysis of the historical landscape dynamics in the Mo River Basin in order to provide up to date information on landscape transformation to support management and planning. With a glance at land management regime, the study specifically aimed at (1) identifying and mapping of the major land/use cover types for the dates 1972, 1987, 2000 and 2014; (2) determining the types and processes of landscape dynamics as well as their rate of occurrence; and (3) assessing the landscape fragmentation and habitat loss over time using FRAGSTAT-based landscape metrics. With regard to the social and ecological importance of the natural landscapes in the area, knowledge on the historical LUCC processes is critical to ensure better future strategies of land management and rural development.

\section{Study area}

The study is carried out in the Mo watershed (Figure 1), a sub-basin of Volta Basin (West Africa). The area is particularly sensitive as it contains great parts of the Fazao - Malfakassa National Park, which is likely to be subjected to more human pressures (Woegan, 2007). The population are mainly rural and farming is the main activity. In 2010 the central region, embedding the Mo River Basin, is the region with the lowest density of population (47 inhbts $/ \mathrm{km}^{2}$ in 2010 versus $21 \mathrm{inhbts} / \mathrm{km}^{2}$ in 1981) compared to $109 \mathrm{inhbts} / \mathrm{km}^{2}$ at the national level (DGSCN, 2010). The Mo basin is part of the Ecological zone 2 of Togo (Ern, 1979), characterized by a mosaic of mountainous dry and open forests, guineo-soudanian savannahs and 


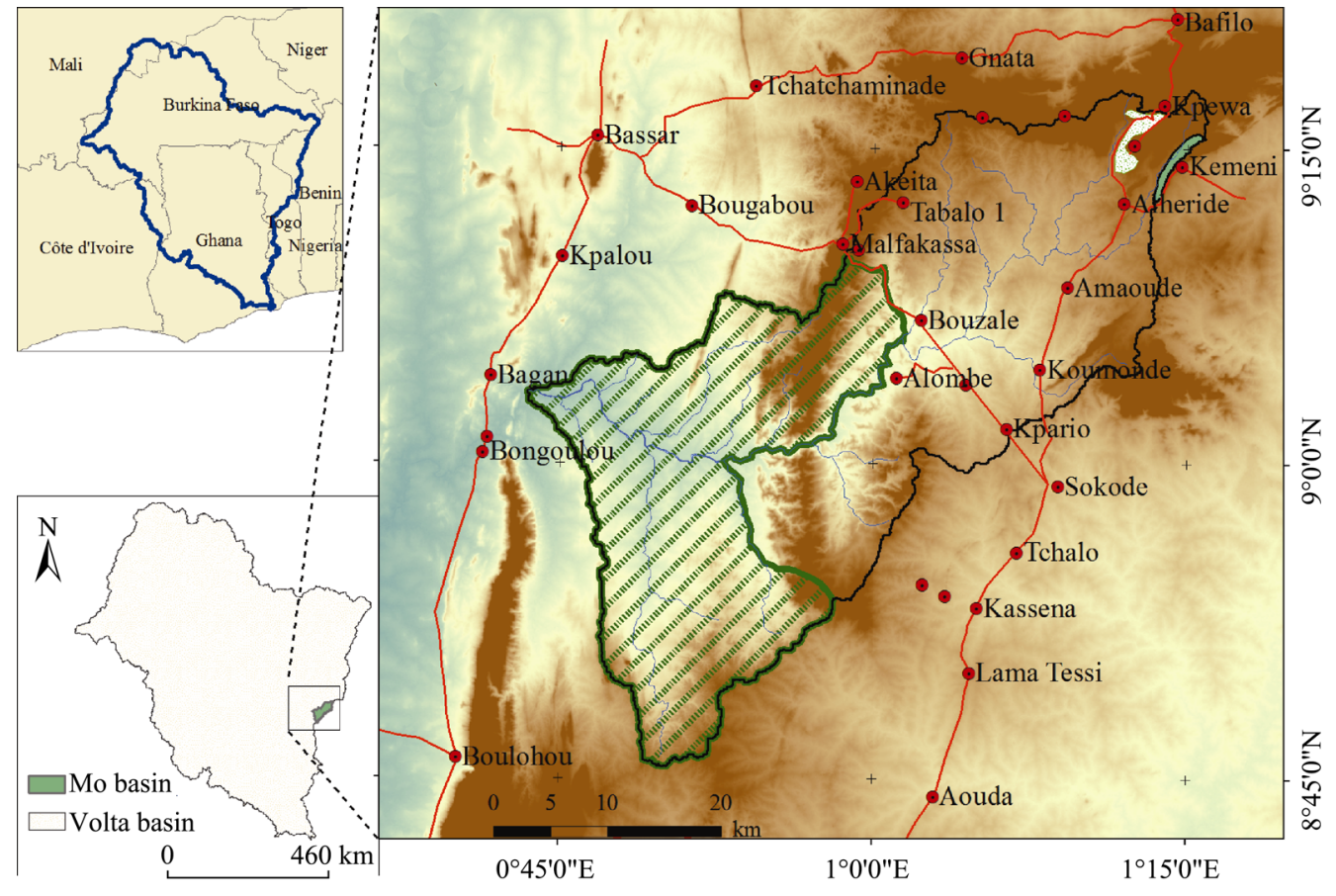

! Main localities

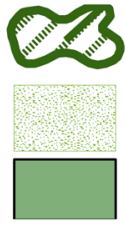

Fazao-Malfakassa National Park

Terrain elevation

$\sim$ Rivers

Aledjo Wildlife Reserve

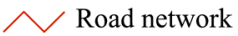

Kemeni Forest Reserve

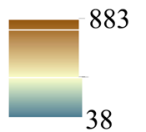

Figure 1 Location of the study area

agro-ecosystems within a human-transformed landscape (UPA) (Dourma et al., 2009). In 1990-1991, with the socio-political crisis in Togo, the population in these areas coming back from the south have increased. Serious inadequate land management took place within this incorrect multiple use of lands. Additionally, local people used to withdraw wood and non-woody products, inducing forest degradation, and in the worst case, deforestation and desertification. Some parts of the hilly lands have an altitude greater than $800 \mathrm{~m}$, especially in Aledjo Mounts. The climate includes cool nights at upland regions, a rainy season from April to October. Mean annual rainfall in the area is between 1200-1300 mm with an irregular spatio-temporal distribution. Mean minimal and maximal temperatures reach respectively $19^{\circ} \mathrm{C}$ in January with the Harmattan winds and $30^{\circ} \mathrm{C}$ in April. The rivers/streams network is heavily developed in accordance with the mountainous relief. Foremost of the land uses in the area is small-scale subsistence farming, pasture lands, PA and built-up areas. The prominent environmental issues are land degradation due to overgrazing, unsustainable agricultural land use, fuel wood harvesting and charcoal production (Wala et al., 2012). Illicit incursions for hunting and tree logging in PA are also concerns that cause conflicts between land users and state agencies protecting lands (Dourma et al., 2009; Woegan, 2007). In addition, protection legislation regarding the PA is weak, and non-inclusive. The catchment is relatively important for tourism and one of the breadbaskets (crop production) of the country. 


\section{Data sources and methods}

\subsection{Mapping the land-use and cover for the period 1972-2014}

Land-use and cover maps of 1972, 1987, 2000 and 2014 for the Mo river basin were obtained from the classification of historical Landsat archives (Jianjun et al., 2005; Pattanaik et al., 2011). Single ortho-rectified images of Landsat 8 (03 December 2014), Landsat ETM+ (04 December 2000) and Landsat TM (30 October 1987) free of cloud were collected at the path 193/row 054 (https://earthexplorer.usgs.gov). A pair of Landsat MSS (10 November 1972) was downloaded from the same source at the path 207/row 053 and path 207/row 054. These data are acquired for the time corresponding to the early dry season onset (October to December), enabling the clear distinction between land use/cover (LUC) types, especially agricultural fields and typical savannahs in the landscape (Traore et al., 2014; Ruelland et al., 2010).

Developing LUC maps was the process of clustering and assigning similar pixels into classes (Rojas et al., 2013). Therefore, to reduce the effects of typical similarities between closer cover types such as savannahs and woodlands, which look similar in savannah-dominated landscapes, a transformation was necessary. Since the study is interested in vegetation cover mapping, normalized difference vegetation index (NDVI) was computed as independent layer not only to reduce the effects of topography but also to measure the distribution of vegetation health over the landscape of interest (Braimoh and Vlek, 2004). NDVI is widely used as a powerful indicator of vegetation greenness, and less sensitive to topographic factors in mountainous areas (Matsushita et al., 2007; Diallo et al., 2010). Original bands were combined with the NDVI layer to perform the pixel-based supervised classification using Maximum Likelihood algorithm in ENVI 4.7 image processing software.

Though topography is a common source of biases in LUC classification in mountainous areas, DEM data were not integrated into the classification process, as the maximal elevation above sea level which is around $850 \mathrm{~m}$, does not really provide significant hill shade at the sensor passing time (Diallo et al., 2010). The combined layers were registered to UTM WGS 84 projection system and used to extract spectral signatures for the classification of the respective images (Braimoh, 2004; Wittig et al., 2007; Gutiérrez Angonese and Grau, 2014).

Six main categories were defined based on the LUC classification scheme from the national vegetation map (Afidégnon et al., 2003). The classification scheme was supplemented by the United Nations Food and Agriculture Organization Land Cover Classification System in order to better consider the physiognomy-structural conditions (vertical and horizontal arrangements as well as land use affected on the cover types) of the vegetation types.

(1) Forests: close canopy vegetation including the riparian forests along streams and dry forests in lowlands. The canopy cover exceeds $60 \%$ with an understory layer.

(2) Woodlands: open canopy vegetation including woody savannahs and woodlands. The canopy cover comprises between $30 \%$ to $60 \%$ and do not possess understory vegetation making their cover less thick compared to forests. Trees are higher than $5 \mathrm{~m}$.

(3) Savannahs: Treeless open canopy vegetation composed of tree savannahs, shrubs, and scattered grasslands. Generally, tree height is lower than $5 \mathrm{~m}$. They have a bush or grass dominant layer with woody coverage less than $30 \%$. This category includes old fallows.

(4) Agricultural land: cultivated (including cereal crops, vegetable crops and fruit orchards) 
and non-cultivated (farm fallows less than 3 years and parklands) lands;

(5) Built-up areas: areas occupied by residential settlements as well as paved surfaces.

(6) Water: surface water bodies including rivers and reservoirs.

Paved surfaces and bare rocks are mostly confused among settlements and agricultural lands since they reflect in the quite similar range.

For each abovementioned LUC type, training areas were developed independently and the spectral characteristics of each training sample were checked through the separability tests of Jeffries-Matusita and Transformed Divergence (Zhou et al., 2008; Braimoh, 2004). The output values of the separability tests range from 0 to 2 , with 0 indicating poor separability and 2 a total separability i.e. the signatures have no similarity among them. For this study, the both separability measures between the defined classes were acceptable.

Collection of reference data to assess the accuracy of historical maps is often a tremendous issue in data scarce areas (Wilson and Sader, 2002). While the collection of such data is less hectic for recent and current images, it is very difficult for images of long history especially due to the lack of reliable data such as aerial photographs (Biro et al., 2013; White et al., 2013; Zhou et al., 2008). Therefore, the data dearth for the current study constrained to the use of different sources of information. Ground truth information for accuracy assessment of classified map of 2014 relied on the use of 177 field-registered GPS coordinates collected based on a random sampling. These points were collected during field campaigns between February and May 2014 corresponding to the dry season and matching the acquisition season of the image. Validation samples of at least 45 pixels were composed of either the raw GPS points or a blend with homogenous polygons around the GPS points. For the validation of LUC map of 2000, we referred to the available topographic map at 1/200000 (IGN, 1986) and vegetation map of Togo (Afidégnon et al., 2003) combined with LUC maps of 2005 and 2009 from GlobCover project (Bicheron et al., 2008). The reclassification of GlobCover images was performed to meet the classification system used in the current study. Historical Google Earth images were helpful in the creation of these validation information. For the early date images (1987 and 1972), homogeneous areas were selected to create representative validation samples based on the detection of unchanged areas (persistent pixels) along the time series. Hence, using the geographic link tool from ENVI software, the validated maps of 2000 and 2014 were overlaid with each of the classified maps for 1987 and 1972 to collect randomly the validation data from the raw unclassified images (Biro et al., 2013; Waiswa, 2011; Lung and Schaab, 2010). Background knowledge of the study area as well as qualitative information from local informants (local elders) were also helpful in the selection of these validation samples sites.

A confusion matrix, the overall accuracy, the Kappa index of agreement were reported for each LUC map. Ultimately, some post-classification analyses were performed to minimize classification errors due to image registration and georeferencing of satellite images. A clump of $3 \times 3$ window was applied to all output maps to eliminate the "salt and pepper" polygons (Petursson et al., 2013; Zhai et al., 2015).

\subsection{Analyses of change and patterns of land use cover types}

The output images were exported to GIS software for change detection analyses between the four individual maps of the basin. Post-classification comparison adopted to detect changes in land-cover types was based on pairwise overlay (bi-temporal analyses) of individual LUC 
maps (Braimoh and Vlek, 2004; Pang et al., 2013; Pang et al., 2010; Badjana et al., 2014). Class statistics, transitions analyses, conversion categories, and annual rates of occurrence were computed from the output LUC maps for each LUC type and transition category (Zhou et al., 2008; White et al., 2013; Tfwala et al., 2012). Statistics were produced for the three transition periods 1972-1987; 1987-2000; 2000-2014 and the overall period 1972-2014.

We detected the gross gains (total gains), gross losses (total losses), net change (i.e. changes in land quantity), and swap changes (i.e. changes in land location) for each LUCC from a pairwise conversion matrix (Braimoh, 2004; Pontius et al., 2004; Schmitt-Harsh, 2013; Carmona and Nahuelhual, 2012). The gross gain for a category i is expressed as the summative value of all areas gained from other LUC types at a final date. Inversely, the gross loss of a LUC category $i$ is the summative value of all areas converted from $i$ into other LUC types. For each LUC type, the total change area was calculated as the sum of all areas affected by changes (i.e. gross gains + gross losses). Hence, the net change was calculated as the simple difference between gross gains and losses during a transition period. Meanwhile, the swap change was derived by subtracting the absolute net change from the total change for the specific LUC type during a given transition period.

The annual net change for each LUC type was calculated according to Equation 1 below (Carmona and Nahuelhual, 2012; FAO, 1996):

$$
C_{R}=\operatorname{In}\left[\frac{S f}{S i}\right] \times \frac{100}{T f-T i}
$$

where $C_{R}$ is the annual rate of change of a cover type, $S f$ is the area of the targeted LUC type at the final time $T f ; S i$ is the area of the same targeted LUC type at the initial time $T i$; $\ln$ is the natural $\log$ function.

Furthermore, we detected the important LUC changes and persistence among the different LUC types for all the transition periods following Pontius et al. (2004). This methodology assumes there is randomness in the landscape transitions when land categories gained from other categories in proportion to the availability of the other losing categories, or reciprocally. Meanwhile the systematic transitions base on the interpretation of the transition proportions relative to the sizes of the categories. A transition is assumed random when the difference between the expected and the actual transition proportions is close to zero while any large value indicates systematic landscape transition (Pontius et al., 2004; Schmitt-Harsh, 2013; Romero-Ruiz et al., 2012). For this study, transitions with an absolute difference value higher than or equal to 0.5 were considered as the most important systematic changes.

In the process of computing proportions for accounting for systematic and random changes, three important variables are used in determining the random and systematic transitions; viz. the observed (actual) transition values, the expected land gains and losses under random processes of gain and loss (Romero-Ruiz et al., 2012; Teferi et al., 2013; Gutiérrez Angonese and Grau, 2014). Whilst the observed transitions were computed from the actual values in the cross-tabulation matrix between two times, equations 2 and 3 were used to calculate the expected gain $\left(\mathrm{G}_{i j}\right)$ and expected loss $\left(\mathrm{L}_{i j}\right)$ of each transition under a random process of gain or loss (Schmitt-Harsh, 2013; Pontius et al., 2004; Nakakaawa et al., 2010).

$$
G_{i j}=\left(P_{+j}-P_{j j}\right)\left(\frac{P_{i+}}{\sum_{i=1} P_{i+}}\right), \text { where } i \neq j
$$




$$
L_{i j}=\left(P_{i+}-P_{i i}\right)\left(\frac{P_{+j}}{\sum_{j=1} P_{+j}}\right), \text { where } i \neq j
$$

where $G_{i j}$ denotes the expected transition from category $i$ to $j$ under random processes of gain, $P_{+j}$ is the proportion of the landscape in category $j$ in the final time; $P_{j j}$ is the observed persistent proportion of the category $j ; \mathrm{P}_{i+}$ is the total area of category $i$ at initial time; $L_{i j}$ is the expected transition from category $i$ to $j$ under random processes of loss; and $P_{i i}$ is the proportion of the category $i$ that showed persistence between the two times.

Loss-to-persistence ratio $L_{(-)}$and gain-to-persistence ratio $G_{(+)}$were also calculated using Equations 4 and 5 to assess the vulnerability of the land classes to transition (Ouedraogo, 2010; Nakakaawa et al., 2010; Braimoh, 2004; Romero-Ruiz et al., 2012). $L_{(-)}$value for a cover category higher than 1 indicates a high vulnerability of that category to be converted into other categories (Gutiérrez Angonese and Grau, 2014). Meanwhile, $G_{(+)}$indicates the tendency of a cover category to gain more from other cover types. These ratios are expressed as follows:

$$
\begin{array}{r}
L_{(-)}=\left(\frac{\text { Observed loss-expected loss }}{\text { Expected loss }}\right), \text { in } \% \\
G_{(+)}=\left(\frac{\text { Observed gain-expected gain }}{\text { Expected gain }}\right), \text { in } \%
\end{array}
$$

\subsection{Landscape fragmentation and degradation using landscape metrics}

Spatial patterns in wild and human-impacted systems are often characterized using not only long-term spatial changes in vegetation cover but also the use of landscape metrics (LMs) helps in identifying and measuring landscape dynamic (Schindler et al., 2013; Renetzeder et al., 2010; Uuemaa et al., 2013; Mander and Uuemaa, 2010; Kang et al., 2013). Hundreds of LMs available for characterizing landscape patterns (i.e. composition and structure) and dynamics but we only selected 5 metrics (Table 1) (Zhang et al., 2013; Wu et al., 2014; Weng,

Table 1 Land cover-based landscape metrics for approximating ecosystem services (ESS) change (McGarigal and Marks, 1995; McGarigal et al., 2002

\begin{tabular}{ll}
\hline \multicolumn{1}{c}{ Indices \& Acronyms } & \multicolumn{1}{c}{ Meaning of index - Measured ESS } \\
\hline Number of patches (NP) & $\begin{array}{l}\text { NP } \geqslant 1 \text {, without limit. NP }=1 \text { when the landscape contains only } 1 \text { patch of the } \\
\text { corresponding patch type. Measure of the extent of class fragmentation } \\
\text { PD has the same basic utility as number of patches as an index, except that it } \\
\text { expresses number of patches on a per unit area basis that facilitates comparisons } \\
\text { among landscapes of varying size. PD }>0 \text {, constrained by cell size. }\end{array}$ \\
Patch density (PD) & $\begin{array}{l}\text { Largest patch index quantifies the percentage of total landscape area comprised by } \\
\text { the largest patch. As such, it is a simple measure of dominance. } 0<\text { LPI } \leqq \\
\text { LPI approaches } 0 \text { when the largest patch in the landscape is increasingly small. }\end{array}$ \\
Pargest patch index (LPI) & $\begin{array}{l}\text { Patch cohesion index measures the physical connectedness of the corresponding } \\
\text { patch type. } 0<\text { COHESION }<100 ; \text { COHESION approaches } 0 \text { as the proportion } \\
\text { of the landscape comprised of the focal class decreases and becomes increas- } \\
\text { ingly subdivided and less physically connected. } \\
0 \leqq \text { AI } \leqq 100 . \text { Aggregation index is calculated from an adjacency matrix, } \\
\text { which shows the frequency with which different pairs of patch types (including } \\
\text { like adjacencies between the same patch types) appear side-by-side on the map. }\end{array}$ \\
Aggregation index-AI &
\end{tabular}


2007; Wang et al., 2013; Wala et al., 2012) to evaluate landscape fragmentation at class level using FRAGSTATS 4.2.1 (McGarigal and Ene, 2013). Using 8 cell neighborhood rule, at only class and landscape levels, LMs were calculated for the four epochs at the whole watershed scale without any sampling.

\section{Results}

\subsection{Historical land use/cover change and geographic patterns}

During the last four decades, major transformations affected the landscapes of the Mo river basin (Figures 2 and 3). On the spatial angle, the central and the northeastern areas of the basin were dominantly covered by human systems (croplands and settlements), especially in 2000 and 2014. Most of the greenest areas from 1972 to 2014 lay within the PA, especially
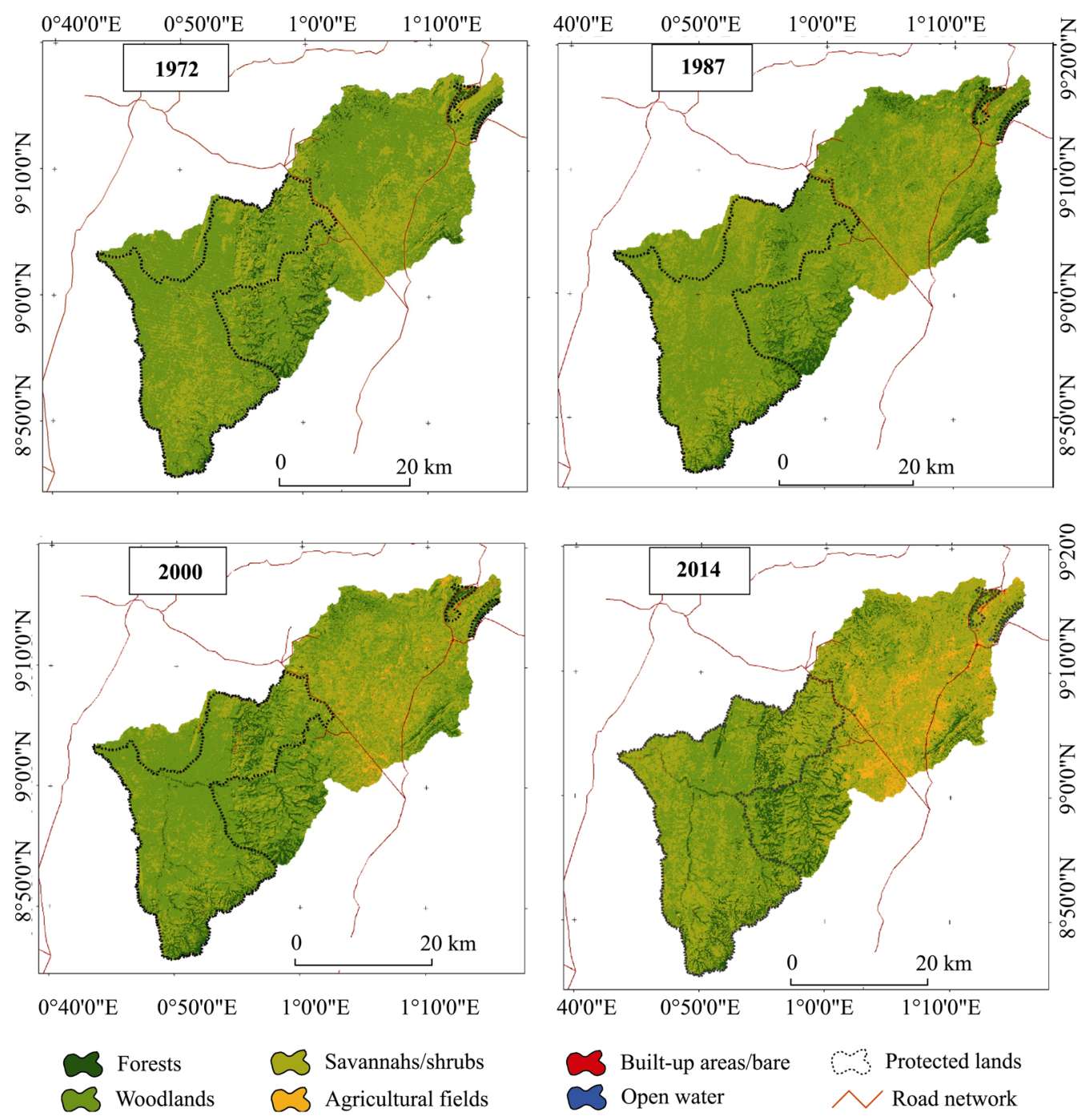

Figure 2 Historical patterns of LUC types in the Mo River basin (Note: The legend is dedicated to the four LUC maps) 

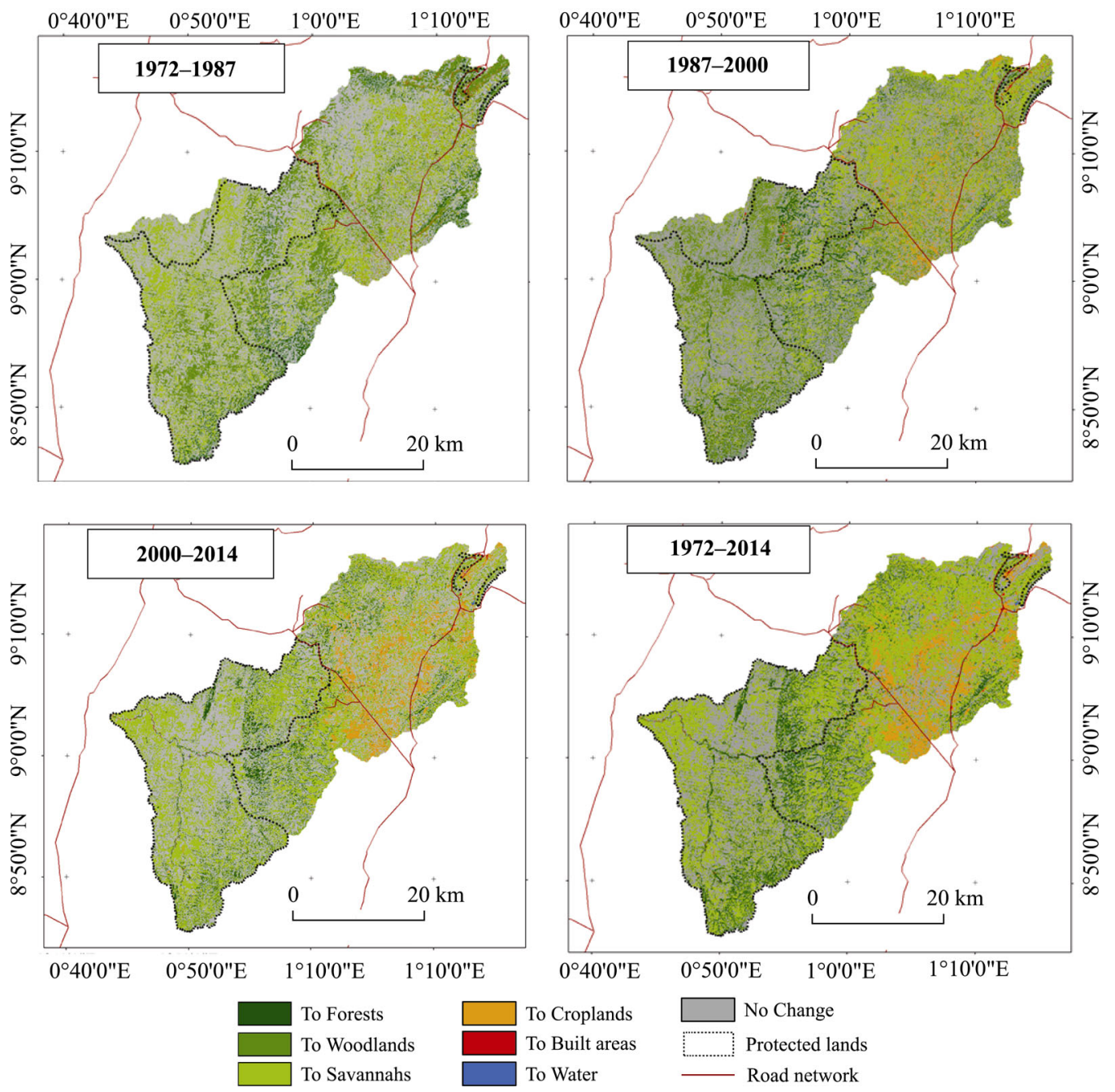

Figure 3 Historical LUCC in the Mo River basin Note: The legend is dedicated to the four LUCC maps

the Fazao-Malfakassa National Park in the southern and western parts of the basin. Savannahs and shrubs were the most scattered LUC types from the earlier dates to the most recent years. Some scattered patches of forests and woodlands were located within the most human-dominated parts, decreased markedly from 1972 to 2014. Meanwhile, the emergence of forest was marked along river network within the PA whereas in the free access lands, their cover decreased constantly over time. Built-up areas mostly developed in the eastern parts along the main road network.

In terms of the areal distribution, natural vegetation dominated the landscapes and decreased from $99 \%$ in 1972 to $98 \%, 96 \%$ and 91\%, respectively in 1987, 2000 and 2014 (Tables $2 \mathrm{a}, 2 \mathrm{~b}, 2 \mathrm{c}$ and $2 \mathrm{~d}$ ). The most dominant LUC types over time were woodlands and savannahs. While the total area of the woodlands decreased from 94,829 ha in 1972 to 40,527 ha in 2014, savannahs increased from 45,000 ha (30\%) in 1972 to about 79,000 ha (53\%) in 2014. The proportion of forests was about $6 \%$ of the total area in 1972 and slightly increased to $6 \%, 9 \%$ and $11 \%$ for 1987,2000 and 2014 , respectively. Over the period 1972-2014, 
there was an increasing forest coverage. Croplands significantly increased from $0.2 \%$ in 1972 to $8 \%$ in 2014. Similar to the croplands, built-up areas also showed an increasing trend all over the years but still exhibit very low values. All LUC types experienced unidirectional changes between 1972 and 2014, with the exception of water areas which varied in relation to the water levels of Aleheride and Aledjo dams and the riverbeds. In general, the class statistics indicated high wildness and rurality of the study area where agricultural expansion and settlement growth are increasing the trend of human-appropriation of the landscapes.

\subsection{Change rates, persistence, gains and losses of land use/cover types}

Forests gained about 791 ha, 3497 ha and 3712 ha respectively for the three transition periods. Though forests gained over all the periods, the annual rates of gain decreased during the second and third transition periods (Tables $2 \mathrm{~b}$ and $2 \mathrm{c}$ ). The swap changes for forest coverage were of $7.2 \% ; 6.9 \%$ and $5.9 \%$ for the ordered transition periods. The swapping values were quite higher than the respective absolute net changes $(0.5 \% ; 2.4 \%$ and $2.5 \%)$, suggesting that forest regeneration (gain from other cover types) and degradation or deforestation (loss to other types) during all the transition periods affected much more spatial coverage than the proportions revealed through the net changes. However, the overall net $(5.4 \%)$ and swap (6.1\%) changes over the period 1972-2014 were close, indicating that forest change processes (loss and gain) affected mostly great proportions of its initial spatial coverage in addition to the net gain of about $0.7 \%$ of new forest areas.

Similar to forests, savannahs showed a constant increase in coverage passing from a net gain of 3051 ha ( $1.3 \%$ of initial areas) during the period 1 to approximated net gains of 1876 ha $(1.3 \%)$ and 29028 ha (19.6\%) during the transition periods 2 and 3, respectively (Tables 2). However, land transformation processes affected much more coverage (high swap values of $34.6 \%, 34.7 \%$ and $21 \%$ for periods 1,2 , and 3 , respectively). The transition period 2 showed the lowest annual rate of gain $(0.3 \%)$ while the period 3 experienced the highest processes of savannah gain (3.3\%). In overall, the net $(23 \%)$ and swap $(25 \%)$ changes showed that the processes of savannah gain and loss affected quite same landscapes, even if there was an additional $2 \%$ of savannah cover change not captured through the net change. This category has the highest value of swapping (25.11\%), suggesting a constant transformation (losses to and gains from other categories) of savannahs during the overall period, which affected about $52.3 \%$ of the total changes in this category.

In contrast, woodlands experienced net losses of about 3.9\% (5738 ha), 5.4\% (7987 ha) and $27.3 \%$ (40,519 ha) of their initial coverage during the three periods, respectively (Tables 2 ). Similar to savannahs, woodlands experienced the high swap changes of $38.2 \%$ and $35.6 \%$ during the first two periods, indicating that woodlands experienced high exchanges of coverage location (gain and loss) with other categories. However, the swapping in woodlands decreased during the third period $(12.3 \%)$ because this cover type considerably decreased over time while gained only $6.2 \%$ from other categories. Between 1972 and 2014, woodlands had a net loss of about $36.7 \%$ out of $49.3 \%$ of total change at an annual rate of $-2 \%$. The highest rate of woodland loss occurred during the period 1987-2000. The swapping were quite fair $(12.7 \%)$ suggesting that the changes in woodland locations did not occur much more as revealed from the transition periods. During the overall time, the swapping for woodlands represented about $26 \%$ of the total change, which is lower than the decreasing 

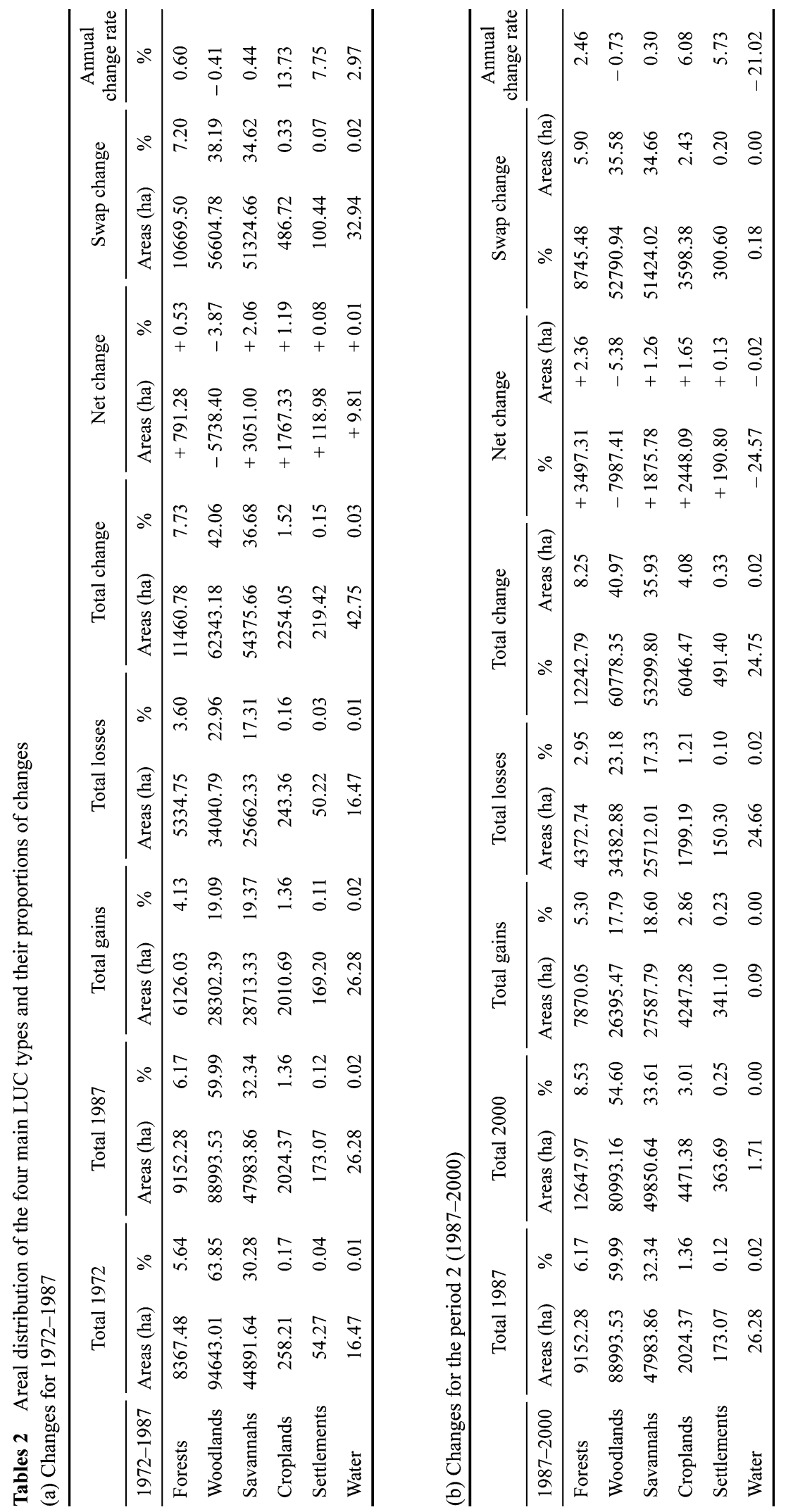


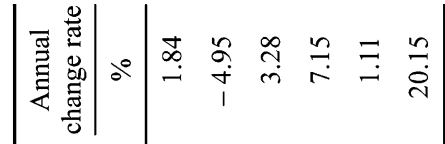

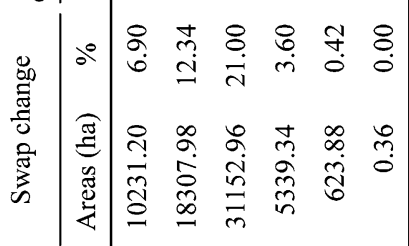

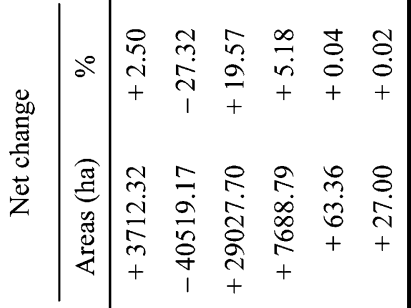

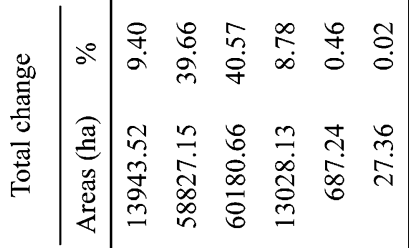

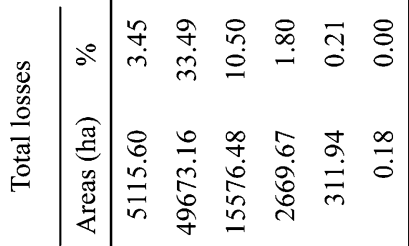

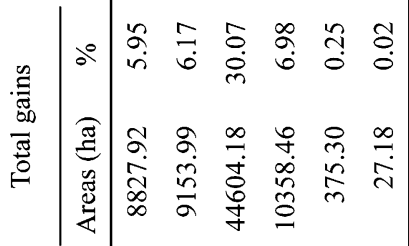

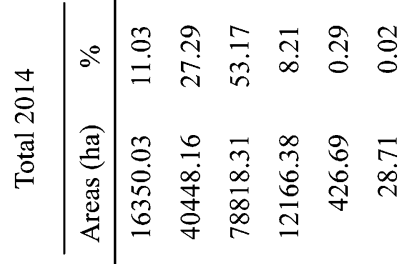

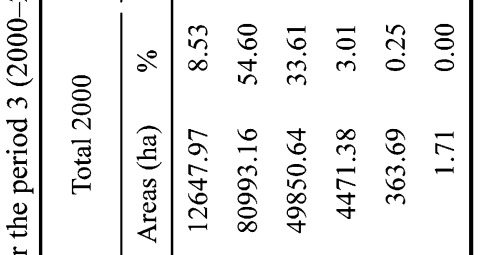

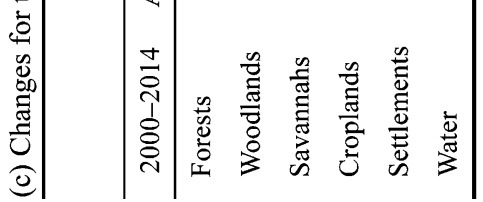

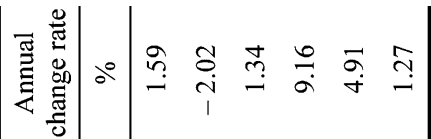

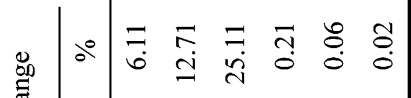

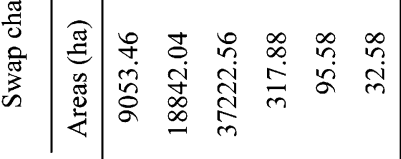

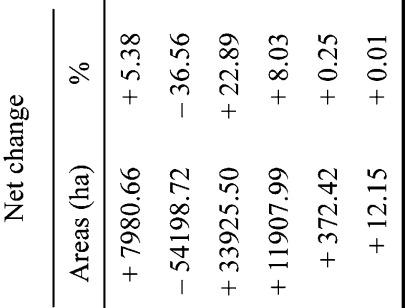

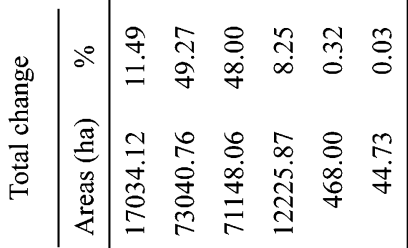

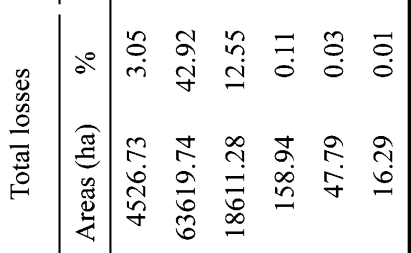

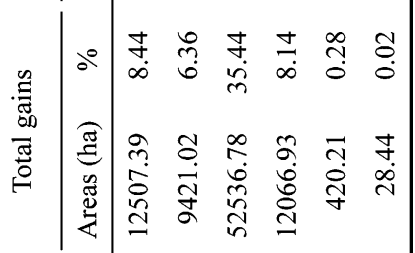

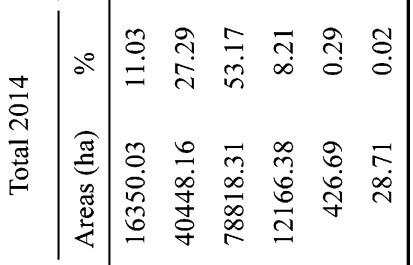

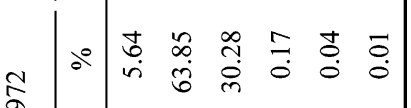

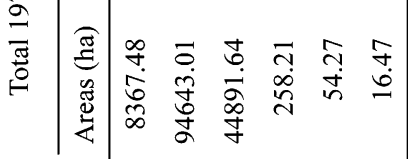

$$
\begin{aligned}
& \stackrel{ \pm}{\Xi}
\end{aligned}
$$

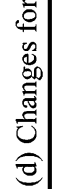

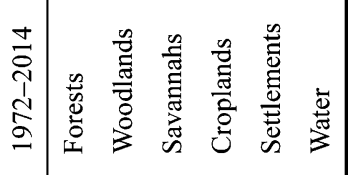


swap changes for this category during transition periods $(91 \%, 87 \%$, and $31 \%$ for the 3 periods, respectively).

During the three transition periods, transformations affecting cultivated land consisted of both swap and net changes (Tables 2). While net gains of croplands increased over time, the swapping affected additional areas passing from $0.3 \%$ between 1972 and 1987 to $2.4 \%$ and $3.6 \%$ for the transition periods 2 and 3, respectively. Thus, cultivated lands showed high tendency to gain from other land categories much more than to lose, suggesting that more intensive as well as extensive cultivation occurred in the Mo basin landscapes over the past 42 years. Over all the three time intervals, similar trends were observed for human settlements as their expansion induces agricultural lands in the meanwhile. For all the three periods, swap changes of these settlements far exceeded the observed net changes, meaning that all the areas affected by settlement expansion were underestimated by the net change results.

\subsection{Land use cover persistence, systematic and random conversions}

Land cover persistence dominated the landscape (more than $50 \%$ as sum of first lines of diagonal values in Tables 3). The persistence constantly decreased and accounted for $56 \%$, $55 \%$, and $50 \%$ of the landscape, respectively for the ordered 3 transition periods. About 59\% (100-sum of the diagonal entries in first lines, in Tables 3) of the landscape did change during the overall 42-year period. Natural vegetation dominated the persistence with woodlands

Tables 3 Matrices for the four periods under investigation in the Mo basin (a) Period 1 (1972-1987)

\begin{tabular}{|c|c|c|c|c|c|c|c|c|}
\hline & & \multicolumn{4}{|c|}{ Year 1987} & \multirow[b]{2}{*}{ Total 1972} & \multirow[b]{2}{*}{ Gross loss } & \multirow[b]{2}{*}{$\mathrm{L}_{(-)}$} \\
\hline & & Forests & Woodlands & Savannahs & Croplands & & & \\
\hline \multirow{12}{*}{$\begin{array}{l}\text { Year } \\
1972\end{array}$} & \multirow{3}{*}{ Forests } & $\underline{2.05}$ & 3.22 & 0.36 & 0.01 & 5.64 & 3.60 & \multirow{3}{*}{1.76} \\
\hline & & $2.05(0.00)$ & $2.98(0.24)$ & $1.55(-1.18)$ & $0.08(-0.07)$ & $6.66(-1.02)$ & $4.61(-1.01)$ & \\
\hline & & $2.05(0.00)$ & $2.30(0.92)^{*}$ & $1.24(-0.88)^{*}$ & $0.05(-0.04)$ & $5.65(0.00)$ & $3.60(0.00)$ & \\
\hline & \multirow{3}{*}{ Woodlands } & 3.54 & $\underline{40.88}$ & 18.89 & 0.50 & 63.85 & 22.96 & \multirow{3}{*}{0.56} \\
\hline & & $2.80(0.74)$ & $40.88(0.00)$ & $17.74(1.15)$ & $0.87(-0.37)$ & $62.37(1.48)$ & $21.49(1.48)$ & \\
\hline & & $3.55(0.00)$ & $40.88(0.00)$ & $18.56(0.34)$ & $0.78(-0.28)$ & $63.85(0.00)$ & $22.96(0.00)$ & \\
\hline & \multirow{3}{*}{ Savannahs } & 0.59 & 15.78 & $\underline{12.97}$ & 0.84 & 30.28 & 17.31 & \multirow{3}{*}{1.33} \\
\hline & & $1.33(-0.74)$ & $15.99(-0.21)$ & $12.97(0.00)$ & $0.41(0.43)$ & $30.75(-0.46)$ & $17.77(-0.46)$ & \\
\hline & & $1.58(-0.99)^{*}$ & $15.35(0.44)$ & $12.97(0.00)$ & $0.35(0.49)$ & $30.28(0.00)$ & $17.31(0.00)$ & \\
\hline & \multirow{3}{*}{ Croplands } & 0.00 & 0.07 & 0.09 & $\underline{0.01}$ & 0.17 & 0.16 & \multirow[t]{3}{*}{16} \\
\hline & & $0.01(-0.01)$ & $0.09(-0.02)$ & $0.05(0.04)$ & $0.01(0.00)$ & $0.16(0.02)$ & $0.15(0.02)$ & \\
\hline & & $0.01(-0.01)$ & $0.10(-0.03)$ & $0.05(0.03)$ & $0.01(0.00)$ & $0.17(0.00)$ & $0.16(0.00)$ & \\
\hline & \multirow{3}{*}{ Total 1987} & 6.18 & 59.98 & 32.34 & 1.37 & 100.00 & 44.09 & \\
\hline & & 6.18 & $59.98(0.00)$ & $32.34(0.00)$ & $1.37(0.00)$ & $100.00(0.00)$ & $44.06(0.02)$ & \\
\hline & & $7.19(-1.01)$ & $58.66(1.32)$ & $32.84(-0.50)$ & $1.20(0.17)$ & $100(0.00)$ & $44.09(0.00)$ & \\
\hline & \multirow{3}{*}{ Gross gain } & 4.13 & 19.09 & 19.37 & 1.36 & 44.09 & & \\
\hline & & $4.13(0.00)$ & $19.09(0.00)$ & $19.37(0.00)$ & $1.36(0.00)$ & $44.08(0.00)$ & & \\
\hline & & $5.14(-1.01)$ & $17.77(1.32)$ & $19.87(-0.50)$ & $1.19(0.17)$ & $44.08(0.00)$ & & \\
\hline & $\mathrm{G}_{(+)}$ & 2.01 & 0.47 & 1.49 & 136 & & & \\
\hline
\end{tabular}


(b) Period 2 (1987-2000)

\begin{tabular}{|c|c|c|c|c|c|c|c|c|}
\hline & & & Year 2000 & & & & & \\
\hline & & Forests & Woodlands & Savannahs & Croplands & Total 1987 & Gross loss & $\mathrm{L}_{(-)}$ \\
\hline Year & Forests & $\underline{3.22}$ & 2.52 & 0.42 & 0.01 & 6.17 & 2.95 & \\
\hline 1987 & & $3.22(0.00)$ & $2.74(-0.23)$ & $1.70(-1.28)$ & $0.18(-0.17)$ & $7.85(-1.68)$ & $4.63(-1.68)$ & 0.92 \\
\hline & & $3.22(0.00)$ & $1.76(0.76)^{*}$ & $1.08(-0.66)^{*}$ & $0.10(-0.09)$ & $6.17(0.00)$ & $2.95(0.00)$ & \\
\hline & Woodlands & 4.77 & $\underline{36.81}$ & 17.25 & 1.09 & 59.99 & 23.18 & \\
\hline & & $3.39(1.38)$ & $36.81(0.00)$ & $16.49(0.76)$ & $1.74(-0.65)$ & $58.57(1.42)$ & $21.76(1.42)$ & 0.63 \\
\hline & & $4.35(0.42)$ & $36.81(0.00)$ & $17.16(0.09)$ & $1.54(-0.45)$ & $59.99(0.00)$ & $23.18(0.00)$ & \\
\hline & Savannahs & 0.52 & 14.92 & $\underline{15.01}$ & 1.74 & 32.34 & 17.33 & \\
\hline & & $1.83(-1.31)$ & $14.38(0.54)$ & $15.01(0.00)$ & $0.94(0.80)$ & $32.24(0.11)$ & $17.22(0.11)$ & 1.15 \\
\hline & & $2.23(-1.70)^{*}$ & $14.25(0.67)^{*}$ & $15.01(0.00)$ & $0.79(0.95)^{*}$ & $32.34(0.00)$ & $17.33(0.00)$ & \\
\hline & Croplands & 0.01 & 0.33 & 0.85 & $\underline{0.15}$ & 1.36 & 1.21 & \\
\hline & & $0.08(-0.07)$ & $0.61(-0.27)$ & $0.38(0.48)$ & $0.15(0.00)$ & $1.21(0.15)$ & $1.06(0.15)$ & 8.07 \\
\hline & & $0.11(-0.10)$ & $0.68(-0.35)$ & $0.42(0.43)$ & $0.15(0.00)$ & $1.36(0.00)$ & $1.21(0.00)$ & \\
\hline & Total 2000 & 8.53 & 54.60 & 33.61 & 3.01 & 100.00 & 44.79 & \\
\hline & & $8.53(0.00)$ & $54.60(0.00)$ & $33.61(0.00)$ & $3.01(0.00)$ & $100.00(0.00)$ & & \\
\hline & & $9.92(-1.39)$ & $53.57(1.03)$ & $33.71(-0.11)$ & $2.58(0.44)$ & 100.00 & & \\
\hline & Gross gain & 5.30 & 17.79 & 18.60 & 2.86 & 44.79 & $44.79(0.00)$ & \\
\hline & & $5.30(0.00)$ & $17.79(0.00)$ & $18.60(0.00)$ & $2.86(0.00)$ & $44.79(0.00)$ & & \\
\hline & & $6.70(-1.39)$ & $16.76(1.03)$ & $18.70(-0.11)$ & $2.43(0.44)$ & $44.79(0.00)$ & & \\
\hline & $\mathrm{G}_{(+)}$ & 1.65 & 0.48 & 1.24 & 19.07 & & & \\
\hline
\end{tabular}

(c) Period 3 (2000-2014)

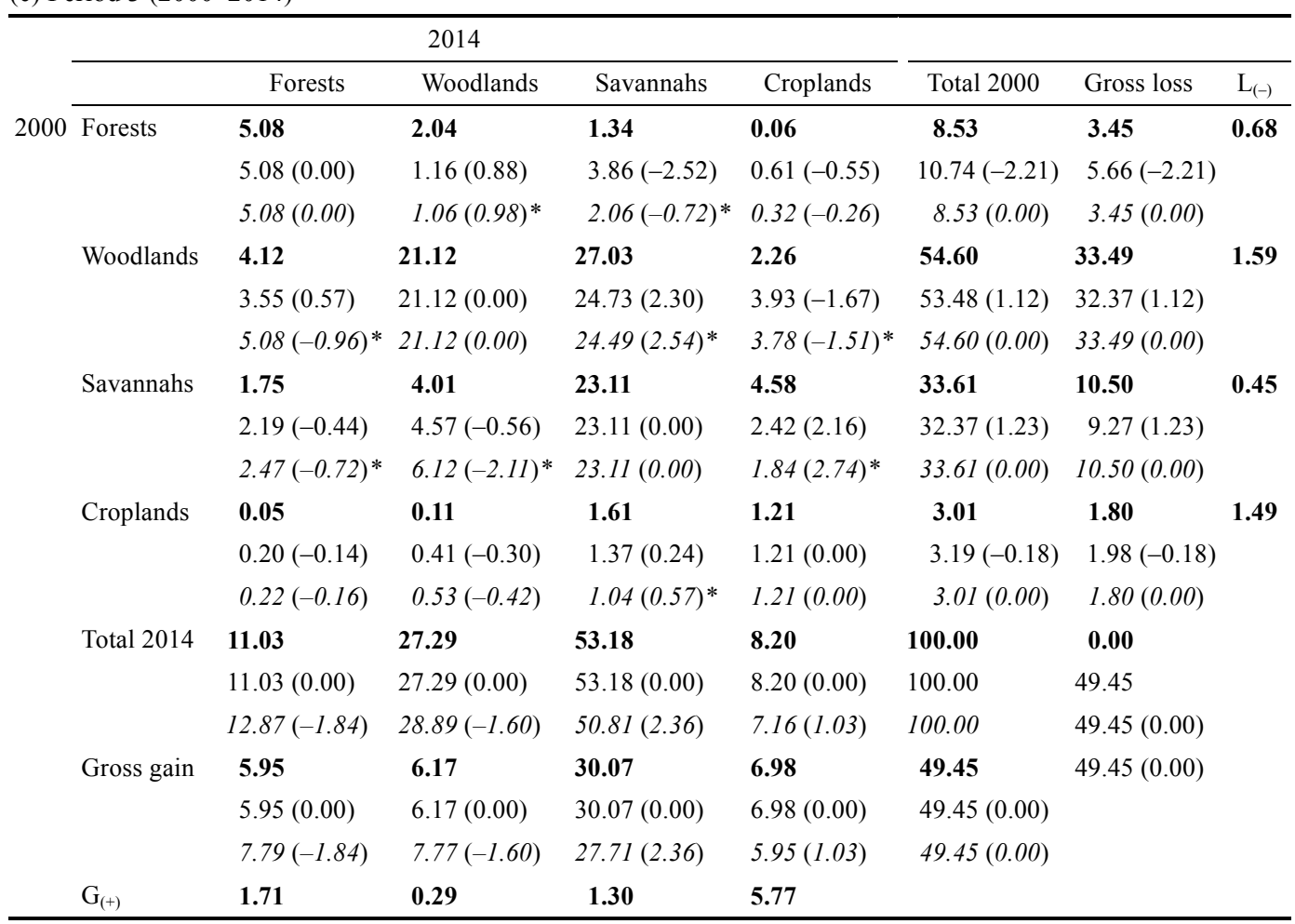


(d) Period 4 (1972-2014)

\begin{tabular}{|c|c|c|c|c|c|c|c|c|}
\hline & & \multicolumn{4}{|c|}{ Year 2014} & \multirow[b]{2}{*}{ Total 1972} & \multirow[b]{2}{*}{ Gross loss } & \multirow[b]{2}{*}{$\mathrm{L}_{(-)}$} \\
\hline & & Forests & Woodlands & Savannahs & Croplands & & & \\
\hline \multirow{19}{*}{$\begin{array}{l}\text { Year } \\
1972\end{array}$} & Forests & 2.59 & 1.18 & 1.76 & 0.11 & 5.65 & 3.05 & 1.18 \\
\hline & & $2.59(0.00)$ & $0.99(0.19)$ & $2.87(-1.11)$ & $0.46(-0.35)$ & $6.95(-1.30)$ & $4.36(-1.30)$ & \\
\hline & & $2.59(0.00)$ & $0.94(0.24)$ & $1.82(-0.06)$ & $0.28(-0.17)$ & $5.65(0.00)$ & $3.05(0.00)$ & \\
\hline & Woodlands & 5.90 & 20.93 & 33.58 & 3.35 & 63.85 & 42.92 & 2.05 \\
\hline & & $5.71(0.19)$ & $20.93(0.00)$ & $32.46(1.12)$ & $5.21(-1.86)$ & $64.68(-0.83)$ & $43.75(-0.83)$ & \\
\hline & & $6.51(-0.61)^{*}$ & $20.93(0.00)$ & $31.38(2.20)^{*}$ & $4.84(-1.49) *$ & $63.85(0.00)$ & $42.92(0.00)$ & \\
\hline & Savannahs & 2.52 & 5.16 & 17.73 & 4.67 & 30.28 & 12.55 & 0.71 \\
\hline & & $2.71(-0.18)$ & $5.32(-0.16)$ & $17.73(0.00)$ & $2.47(2.20)$ & $28.41(1.88)$ & $10.68(1.88)$ & \\
\hline & & $2.96(-0.43)$ & $7.32(-2.15) *$ & $17.73(0.00)$ & $2.20(2.47)^{*}$ & $30.28(0.00)$ & $12.55(0.00)$ & \\
\hline & Croplands & 0.01 & 0.01 & 0.08 & 0.07 & 0.17 & 0.11 & 1.57 \\
\hline & & $0.02(-0.01)$ & $0.03(-0.02)$ & $0.09(-0.01)$ & $0.07(0.00)$ & $0.20(-0.03)$ & $0.14(-0.03)$ & \\
\hline & & $0.01(0.00)$ & $0.03(-0.02)$ & $0.06(0.02)$ & $0.07(0.00)$ & $0.17(0.00)$ & $0.11(0.00)$ & \\
\hline & Total 2014 & 11.03 & 27.29 & 53.17 & 8.21 & 100.00 & 58.68 & \\
\hline & & $11.03(0.00)$ & $27.29(0.00)$ & $53.17(0.00)$ & $8.21(0.00)$ & 100.00 & $58.68(0.00)$ & \\
\hline & & $12.08(-1.05)$ & $29.22(-1.94)$ & $51.02(2.15)$ & $7.40(0.81)$ & $99.99(0.01)$ & $58.68(0.00)$ & \\
\hline & Gross gain & 8.44 & 6.36 & 35.44 & 8.14 & 58.68 & & \\
\hline & & $8.44(0.00)$ & $6.36(0.00)$ & $35.44(0.00)$ & $8.14(0.00)$ & $58.68(0.00)$ & & \\
\hline & & $9.48(-1.05)$ & $8.29(-1.94)$ & $33.29(2.15)$ & $7.33(0.81)$ & $58.68(0.00)$ & & \\
\hline & $\mathrm{G}_{(+)}$ & 3.26 & 0.30 & 2.00 & 116.29 & & & \\
\hline
\end{tabular}

Note (applicable to Tables 3a, 3b, 3c and 3d): each table contains both the outputs of gain and loss analyses. Each cell is subdivided into three rows and two columns of numbers. Left column of each cell: the first row contains bolded numbers that represent the actual (observed) proportions of inter-categorical transitions (persistence and transitions) of the landscape. The second row represents the expected percentage of land under random processes of gain (named Expected $(+)$ ) calculated using Equation 2, where figures in round parentheses are equal to the observed proportion minus the one expected (named Difference $(+)$ ). The third row contains italicized numbers representing the expected proportion of land under random processes of loss (named Expected (-)) calculated using Equation 3, where numbers within round parentheses represent the observed proportion minus the expected one (named Difference (-)). Extreme right column of the table contains the Loss-to-persistence ratio $\left(\mathrm{L}_{(-)}\right)$while the extreme row is the Gain-to-persistence ratio $\left(\mathrm{G}_{(+)}\right)$. Numbers highlighted in gray represent systematic gain transitions; starred numbers represent systematic loss transitions.

exhibiting the highest but decreasing persistence over time. Meanwhile, the persistence of forests and savannahs constantly increased for all the periods. These categories gained much more from the transformation of woodlands, which persist despite the increasing pressures.

The different types of transitions are indicated in Tables 3a, 3b, 3c, and 3d. Difference values between the observed and expected proportions of the landscapes (values in round parentheses in Tables 3) are used to detect random or systematic transitions. Values closer to zero are indicative of random transition while higher values indicate systematic transitions (But a threshold of $0.5 \%$ was considered for analytical purpose in this study). Most of the major transitions occurred between the four dominant cover categories, viz. forests, woodlands, savannahs and croplands (Tables 3). Over the three and the overall periods, transitions of forests-savannahs indicated large and negative difference values between observed and expected gains for savannahs, ranging from $-1.18 \%(1972-1987)$ to $-2.52 \%(2000-2014)$. These negative values indicate that savannahs did not emerge from forests. Similarly, a 
negative difference value $(-1.12 \%)$ was observed for the overall period 1972-2014, corroborating the general trend of systematic avoidance of the forest replacement under random gain processes for savannahs. The vulnerability of forests to loss was quite evidenced by the loss-to-persistence ratio values higher than one during the first transition and overall periods (Tables $3 \mathrm{a}$ and $3 \mathrm{~d}$ ). However, the gain-to-persistence ratio $(\mathrm{G}+)$ for forests and savannahs were higher than one, indicating that this category gained much more than persistence over time. In contrast, L- of woodlands was of 1.6 for 2000-2014 and 2.1 for 1972-2014 indicating high vulnerability to loss in recent years in comparison to the two first periods where woodlands were less vulnerable $(\mathrm{L}-<1)$.

Conversely, forest gains were not associated with the replacement of savannahs (negative values of difference between observed and expected gains; $-0.74 \% ;-1.31 \% ;-0.44 \%$ and $-0.18 \%$ ). In term of gains, there is a systematic mutual avoidance between forests and savannahs, in line with the trend of the transition of forests-savannahs. Meanwhile, forests systematically gained from woodlands $(0.74 \%, 1.38 \%$, and $0.57 \%)$ rather than savannahs, which exhibited negative values of observed minus expected gains of forests from savannahs. Mostly, savannahs gains during the four periods emerged from the replacement of woodlands, as indicated by the positive values of difference observed-expected gains $(1.15 \%$; $0.76 \%, 2.30 \%$ and $1.12 \%$, respectively for the four periods). Under expected random gain, croplands systematically emerged from savannah losses solely at the rates varying between 0.8-1. In sum, under random process of gain, forests gained more from woodlands than the inverse at relatively very low expected rates (ratio values close to zero). Forests gains during all the periods did not emerge from savannahs, and inversely. Savannahs mostly gained from woodlands rather than from forests while woodlands did not gain from savannahs, except during the period 1987-2000.

On the other hand, as indicated by the positive values of difference between observed and expected losses, forest losses during the three transition periods occurred systematically towards woodlands $(0.92 \% ; 0.76 \%$, and $0.98 \%$, for period 1,2 , and 3 , respectively) rather than savannahs $(-0.88 \%,-0.66 \%,-0.72 \%$, respectively for the periods 1,2 and 3$)$. However, in line with the criteria of systematic change defined in this study (threshold of $0.5 \%$ ), the overall period did not show a systematic gain of woodlands from forests $(0.24 \%$ lower than $0.5 \%)$. Under these random processes of loss, it is expected that the loss of savannahs was systematically converted into woodlands, except the periods $2000-2014(-2.11 \%)$ and 1972-2014 (-2.15\%), indicating that savannahs losses are not associated with woodlands replacement for these latter transition periods. The transition of croplands-natural vegetation showed that when croplands lost, they tended to be converted systematically into savannahs rather than other natural categories. This trend was most acute for the period 2000-2014 with a difference value between observed and expected loss of $0.57 \%$ and at an expecting ratio around 0.5 . Neither savannahs nor croplands lost systematically into forests, as indicated by the low proportions of transition. Croplands exhibited highest values of $\mathrm{G}+$ indicating the agricultural expansion occurred much more than agricultural land abandonment or conversion into other cover categories. These $\mathrm{G}+$ values for croplands were far higher than L- values indicating that croplands are less vulnerable to conversion to other categories than they gain from other categories.

\subsection{Landscape fragmentation and habitat quality change}

In general, the landscape metrics (NP and PD) increased for forests (Table 4a), woodlands 
(Table 4b) and savannahs (Table 4c) from 1972 to 2014 in both PA and UPA. NP and PD for woodlands decreased from 1987 to 2014 in UPA landscapes. Meanwhile savannahs-based NP and PD increased from 1972 to 1987 and decreased constantly from 1987 to 2014. Over time, forest-LPI in PA increased markedly while the inversed trend was observed in UPA. While forest in PA constantly increased, UPA forest cover exhibited a slight improvement in $\mathrm{COH}$ in 2014 after a decrease from 1972 to 2000. Marked changes in landscape metrics were observed for 2014 and 2014, especially in UPA.

Table 4a Fragstat-based landscape indices for forest cover

\begin{tabular}{|c|c|c|c|c|c|c|}
\hline Year & Status & NP & PD & LPI & $\mathrm{COH}$ & AI \\
\hline \multirow[t]{2}{*}{1972} & PA & 55 & 2.20 & 0.28 & 78.31 & 69.96 \\
\hline & UPA & 5 & 0.20 & 0.09 & 71.80 & 75.00 \\
\hline \multirow[t]{2}{*}{1987} & PA & 148 & 5.89 & 2.30 & 91.71 & 59.32 \\
\hline & UPA & 27 & 1.08 & 0.05 & 51.83 & 36.23 \\
\hline \multirow[t]{2}{*}{2000} & PA & 177 & 7.09 & 3.72 & 93.47 & 70.44 \\
\hline & UPA & 18 & 0.72 & 0.01 & 27.93 & 19.15 \\
\hline \multirow[t]{2}{*}{2014} & PA & 338 & 13.47 & 4.01 & 93.84 & 69.19 \\
\hline & UPA & 62 & 2.47 & 0.37 & 73.45 & 53.77 \\
\hline References & & $N P \geqslant 1$ & $\mathrm{PD}>0$ & $0<\mathrm{LPI} \leq 100$ & $0<\mathrm{COH} \leqslant 100$ & $0<\mathrm{AI} \leqslant 100$ \\
\hline
\end{tabular}

$\mathrm{NP}=$ number of patch; $\mathrm{PD}=$ patch density; $\mathrm{LPI}=$ largest patch index; $\mathrm{COH}=$ patch cohesion; $\mathrm{AI}=\mathrm{Aggrega}-$ tion index; $\mathrm{PA}=$ protected areas; $\mathrm{UPA}=$ unprotected areas

Table 4b Fragstat-based landscape indices for woodlands

\begin{tabular}{|c|c|c|c|c|c|c|}
\hline Year & Status & NP & $\mathrm{PD}$ & LPI & $\mathrm{COH}$ & $\mathrm{AI}$ \\
\hline \multirow[t]{2}{*}{1972} & PA & 28 & 1.12 & 47.24 & 99.59 & 87.19 \\
\hline & UPA & 56 & 2.24 & 23.47 & 98.59 & 84.85 \\
\hline \multirow[t]{2}{*}{1987} & PA & 245 & 9.76 & 36.96 & 99.38 & 68.78 \\
\hline & UPA & 787 & 31.35 & 5.61 & 92.72 & 56.09 \\
\hline \multirow[t]{2}{*}{2000} & PA & 296 & 11.86 & 28.16 & 98.56 & 75.43 \\
\hline & UPA & 368 & 14.66 & 2.37 & 90.14 & 62.15 \\
\hline \multirow[t]{2}{*}{2014} & PA & 478 & 19.04 & 3.91 & 89.46 & 63.33 \\
\hline & UPA & 99 & 3.94 & 0.06 & 50.19 & 40.07 \\
\hline References & & $\mathrm{NP} \geqslant 1$ & $\mathrm{PD}>0$ & $0<\mathrm{LPI} \leqslant 100$ & $0<\mathrm{COH} \leqslant 100$ & $0<\mathrm{AI} \leqslant 100$ \\
\hline
\end{tabular}

Table 4c Fragstat-based landscape indices for savannahs

\begin{tabular}{|c|c|c|c|c|c|c|}
\hline Year & Status & NP & $\mathrm{PD}$ & LPI & $\mathrm{COH}$ & $\mathrm{AI}$ \\
\hline \multirow[t]{2}{*}{1972} & $\mathrm{PA}$ & 75 & 3.01 & 24.43 & 98.51 & 85.60 \\
\hline & UPA & 36 & 1.44 & 55.18 & 99.72 & 88.38 \\
\hline \multirow[t]{2}{*}{1987} & $\mathrm{PA}$ & 298 & 11.87 & 26.61 & 98.45 & 76.70 \\
\hline & UPA & 98 & 3.90 & 61.11 & 99.79 & 73.75 \\
\hline \multirow[t]{2}{*}{2000} & $\mathrm{PA}$ & 257 & 10.30 & 25.52 & 95.06 & 71.86 \\
\hline & UPA & 40 & 1.59 & 65.84 & 99.84 & 82.34 \\
\hline \multirow[t]{2}{*}{2014} & PA & 135 & 5.38 & 37.22 & 99.07 & 81.97 \\
\hline & UPA & 40 & 1.59 & 63.27 & 99.76 & 88.92 \\
\hline References & & $\mathrm{NP} \geqslant 1$ & $\mathrm{PD}>0$ & $0<\mathrm{LPI} \leqslant 100$ & $0<\mathrm{COH} \leqslant 100$ & $<\mathrm{AI} \leqslant 100$ \\
\hline
\end{tabular}




\section{Discussion}

\subsection{Land use/cover mapping and accuracy}

The LUC mapping showed that natural vegetation dominated the Mo basin for all the observational dates (1972, 1987, 2000 and 2014). At the early dates of the study period (1972 and 1987), great parts of the Mo landscapes were greener and dominated by woodlands and savannahs. Agricultural patches (360 ha over about 148,600 ha of the whole basin) were merely located around scattered human settlements in the landscapes, especially along the main roads. Despite this dominance of natural vegetation over time, woodlands showed acute areal loss while forests and savannahs substantially increased along the study period. The decline of woodlands and the expansion of savannahs indicated that wood extraction is the main cause of landscape fragmentation and degradation. Similar transformations were observed in adjacent landscapes of the Kara river basin (Badjana et al., 2014) and the upper Northern areas of Togo (Folega et al., 2014b; Folega et al., 2015), where agricultural practices associated with energy wood collection were targeted as prominent factor of natural vegetation loss. Though of small-scale in the study area, agricultural production is regarded as main reason of deforestation and forest degradation in rural areas (Lindstrom et al. (2012).

The reliability of these statistics and trends fundamentally depends on the accuracy of the classified maps measured via the Kappa indices of classification agreement. These Kappa indices (0.6-0.9) and overall accuracies (69\%-92\%) (Table 5) were high enough and satisfactory for modelling of LUCC (Aguirre-Gutiérrez et al., 2012; Monserud and Leemans, 1992; Leh et al., 2013). This resulted in reliable transition maps, which are the products of the individual LUC maps as suggested by Were et al. (2013). The overall accuracies of the transition maps were of $62.9 \%, 82.7 \%, 83.3 \%$ and $62.9 \%$, respectively for the 3 and overall transition periods. Further, the producer and user accuracies not only ascertained the above accuracy statistics but also reported the classification errors, which are mostly due to spectral confusion between cover types (Were et al., 2013). In addition, other factors such as complex topography and vegetation patterns in the Mo basin (Diwediga et al., 2015) could drive a certain level of complexity in spectral responses rendering cumbersome the classification processes with less accurate outputs (Lu, 2006). Furthermore, misclassification errors could be introduced via data used for validation since the scale and the resolutions of the reference data for the past LUC maps were relatively poor. Though such data are of poor resolution for small-scale breakdown and might introduced biases (Verburg et al., 2013), they were of great interest for landscape monitoring in the data-scarce area of the Mo basin. Houet et al. (2010) illustrated that the ongoing challenge related to data availability compels to reliance of multisource data for assessing landscape dynamics.

\subsection{Historical trends and processes of land use/cover change in the Mo basin}

Through the analyses of LUCC in the contrasting landscapes (i.e. land protection status), large complex transformations occurred at the whole landscape level. All the LUC types experienced transformations at the early stages of the study period. This significant decrease in the quality of natural vegetation cover was mostly due to agricultural deforestation and wood product extraction (Dourma et al., 2009). In the neighbouring Basin of Kara River with higher human density, similar trends of natural vegetation were recorded with higher 


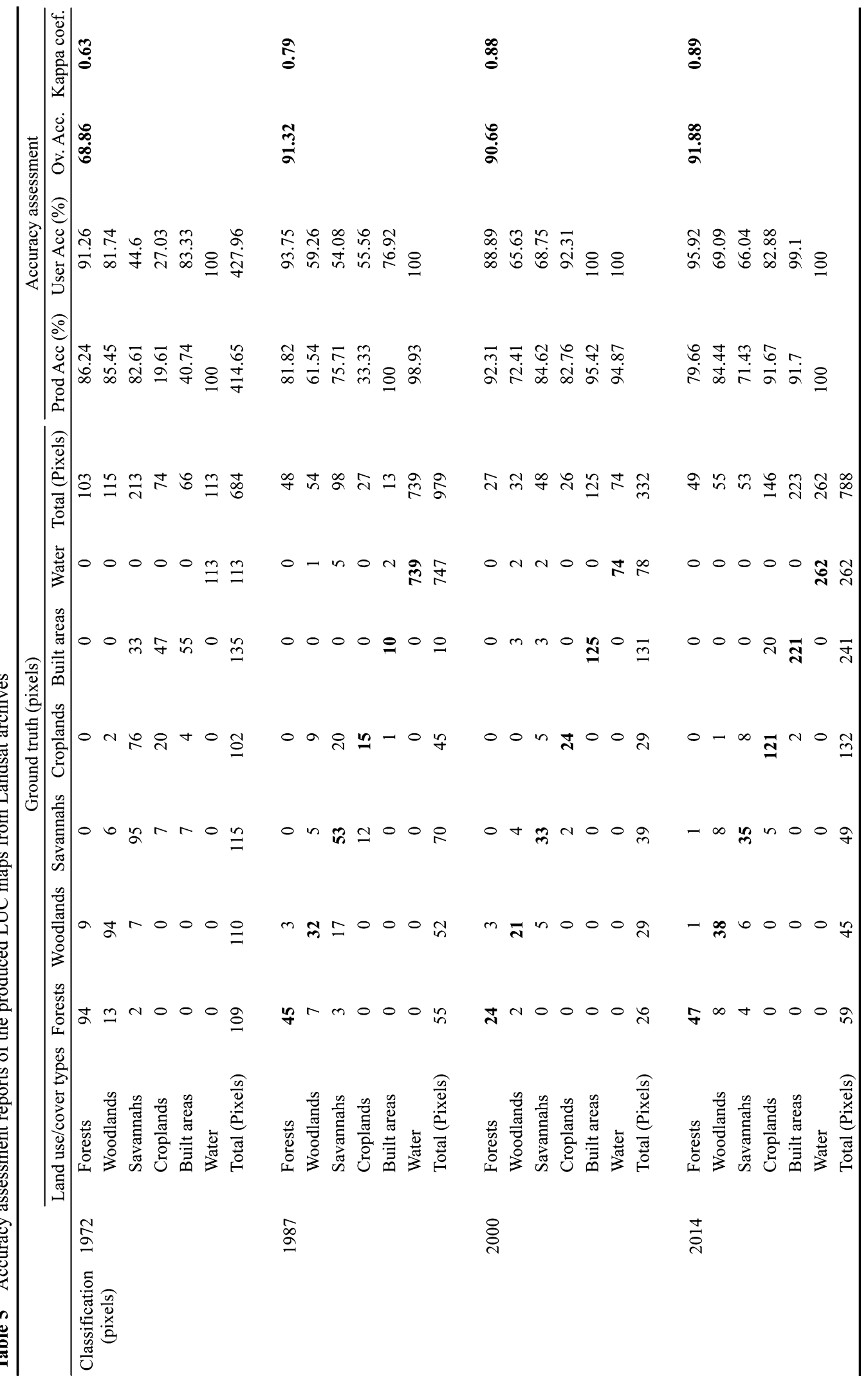


proportions of changes (Badjana et al., 2014). Combined with the large network of PA, human concentration on common lands of UPA induced much landscape degradation and fragmentation, expressed throughout the landscape metrics. The increase over time in the natural vegetation metrics (NP and PD) is an indicator of the decrease of landscape homogeneity across the river basin. Further, LPI, COH and AI decreased constantly over time indicating the increasing loss of landscape and habitat connectivity. Decreasing NP and PD of savannah expressed their increasing level of compactness (increasing savannah-specific LPI, $\mathrm{AI}$ and $\mathrm{COH}$ ) and their dominance of the basin (Diwediga et al., 2015). Similar trends observed in LM for both PA and UPA demonstrate the weak level of protective law enforcement regarding the PA in the river basin (Wala et al., 2012; Diwediga et al., 2015), though natural processes had been shown as drivers of vegetation change in West Africa environments (Traore et al., 2015; Le et al., 2012). However, the Mo basin still exhibits high potential of wild landscapes attributable to the low populated compared to other regions of the country (DGSCN, 2010) associated with the high proportion of PA and landscape ruggedness.

Typically, LUCC processes were not only quantitative (i.e. amount or net change) but also qualitative (i.e. location or swapping) (Pontius et al., 2004; Schmitt-Harsh, 2013). Indeed, the swap changes of the natural vegetation categories were higher and greater than the absolute net changes, especially for woodlands and savannahs over time, suggesting that these LUC types experienced much more spatial transformation than perceived by the net change detection, during the transition periods. However, the constant swap decrease was an indicator of a decrease in recovery (due to human pressures) and loss (due especially to less availability of natural lands) of natural vegetation. Sole forest category exhibited quite stable values of swap changes when the extent of analyses is large (1972-2014). For the overall period, the fair swaps for savannahs and woodlands suggest that changes in their locations occurred lesser than as revealed by the transition periods. Thus, the length of transition period (number of years) is important factor affecting the detection of swapping processes, as longer periods tend to mask land transformations occurred in-between the observational dates. This indicates that the landscape is under perpetual dynamics which detection and acuity are consistent with high temporal resolutions (regular and closer observational dates). In the current study, the mapping approach exclusively relied on the landscape cover at the exact passing times of the satellite, which could not really reflect the LUC dynamics (Braimoh and Vlek, 2004). Although it has limits in the verification of the potential changes that occurred in-between the two successive dates (Braimoh and Vlek, 2005; Garedew, 2010), the approach was helpful for analyzing the historical land dynamics in the data scarce case of the Mo basin.

\subsection{Landscape dynamics, land legislation and implications for sustainable land management}

Regardless of the land protection status and the transition periods, the processes of change affected approximately 50\% of the lands in the whole basin between 1972 and 2014. Persistent natural vegetation and processes of vegetation growth are becoming scarce in both PA and UPA. With a focus on the efficiency of law enforcement on biodiversity conservation, protection law played an important role for land conservation, though vegetation loss occurred in the nature reserves and parks. In fact, illegal incursions were noticed in PA, espe- 
cially the Wildlife Reserve of Aledjo (Wala et al., 2012) and the national park of Fazao-Malfakassa, especially in the neighborhoods of Alombe and along Mo and Bouzalo rivers since 1978 (Aboudou, 2012). Despite the conservation measures, these types of wilderness loss were also reported in other PA of Northern Togo with more acute levels of degradation (Dimobe et al., 2014; Folega et al., 2010; Folega et al., 2012). The fortunate situation of the PA in the Mo basin is attributable to the private status devolved to FMN Park especially during the period 1990-2015. Though it occurs at low rate compared to the situation outside PA, the decrease of natural vegetation should be of major concern to counter-act degradation scenarios similar to those of other PA of Togo (Folega et al., 2014; Wala et al., 2012). Nevertheless, the relative low rates of occurrence compared to the situation in UPA are indicators of the importance of PA in conserving land resources (Fan et al., 2013; Porter-Bolland et al., 2012). However, national government efforts are explicit towards the law reinforcement for PA. This is the case of FMN Park, which regained much more attention through two major concrete actions: (i) the assignment of the park to a private monitor and manager for 25 years (1990-2015) and (ii) redefinition of new boundaries that take somehow into account rural people needs.

The systematic transition of woodlands into savannahs and the expansion of agricultural land from savannah should be key indicators of land conservation challenges in the area. Without effective law enforcement within PA and conservation efforts and sensitisation in UPA, further decline in natural vegetation will continue affecting the Mo river landscapes. With regard to these trends, pro-active approaches need to be undertaken to counter-act the current nature and spatial patterns of degradation and address the underlying factors of these change (Lambin et al., 2003). This study showed that timely acute and spatial information could be drawn from satellite images at landscape level to detect hotspot areas where efforts should concentrate for conservation and restoration processes. Efforts should concentrate to reduce or impede the processes inducing land cover quality loss in both PA and UPA through effective institutional operationalisation at local and national level regarding land question to ensure a holistic framework for sustainable land use and conservation. This suggests a clear definition of land tenure regime that addresses major challenges regarding the management of common resources, especially outside PA where land resource allocation decision-making is uncontrolled and guided by individual household needs. Institutional and political settings towards land governance is a key cornerstone that should be clearly set as basis for sustainability (Paudel et al., 2015). The revision of current national policy regarding the redefinition of PA network in Togo needs careful consideration of the real needs of surrounding communities to avoid breaking the law (Vedeld et al., 2012; Tumusiime et al., 2011). Meanwhile, common lands outside PA might gain much more attention towards sustainable use in order to avoid issues related to common resources. Furthermore, focus should be given to the definition of a clear land information system and the role of all stakeholders from formal to informal as well as public-private partnership in rural communities. Reducing the dependence of households on forest products tend to be of positive effect in the process of landscape conservation. Therefore socio-economic conditions of rural households should be strengthened through diversification of income-generated activities. These options could be the promotion of orchards and cashew plantations, and agroforestry systems in current farmlands which could support social-ecological development (Mbow et al., 2014b; Mbow et al., 2014a). REDD + implications of such strategies could be source of incentives 
for reducing land decline in the area (Mattsson et al., 2012; Nakakaawa et al., 2010).

\section{Conclusion}

Since there is a lack of information on the historical patterns of LUC in developing countries, the reliance on proxies such as the earth observation archives seems to be interesting to monitor landscape transformation and its factors. In this study, the use of historical Landsat data provided an assessment of the process of vegetation cover degradation in rural areas of the Mo river basin. The study provided more light on the extents, locations and rates of rural land transformation, mainly deforestation and forest degradation (DFD). The results revealed that the observed trend in the study area are the intensive decline of woodlands associated with an increase in savannah and forest extents as well as cultivated areas. Despite the important network of PA in the area, natural vegetation showed a decreasing trend from $99 \%$ in 1972 to $91 \%$ in 2014 . This significant change in the natural land cover quality and extent were due to agricultural expansion and wood extraction in both PA and UPA. The trend in the landscape dynamics indicated a savannisation process throughout the river basin though there was an improvement of forest cover. The net balance of natural vegetation changes indicated an overall loss mostly due to woodland decline. However, there Mo basin still provides wide landscapes for wilderness protection and natural landscape integrity (Diwediga et al., 2015). This information may be of practical aspect in guiding managers and policy makers for reversing the loss of natural vegetation through the formulation and implementation of new strategies for the integrated land management. Restoring degraded areas and increasing awareness to maintain the quantity and quality of the natural vegetation are essential for supporting livelihood, biological conservation and global climate mitigation. With regard to the ecological and economic importance of the Mo river basin and its surrounding lands, attempting focus towards the reduction of vegetation decline, should be given through further analyses of the major trajectories of conversion, the underlying factors as well as the direct drivers, and the modelling of possible pathways of sustainable development of the basin.

\section{Acknowledgments}

This study is part of a PhD research performed within the WASCAL (West African Science Service Center on Climate Change and Adapted Land Use) program on Climate Change and Land Use, funded by the German Federal Ministry for Education and Research (BMBF) and hosted by the Kwame Nkrumah University of Science and Technology of Kumasi, Ghana. We are grateful to the Laboratory of Botany and Plant Ecology (University of Lome, Togo) for fieldwork support. We acknowledge the contribution of CGIAR-DS through the funding to Quang Bao Le. May the soul of the late supervisor (Dr E. Ofori) of the first author rest in peace. Thanks to the unknown reviewers for their invaluable contributions to the work.

\section{References}

Aboudou M, 2012. Etat des lieux de l'occupation du sol dans et autour du parc national Fazao-Malfakassa. MERF-Togo/Fondation Franz Weber.

Afidégnon D, Guelly K A, Kokou K et al., 2003. Carte de la végétation du Togo + Notice explicative. Projet 
Campus 96.348.110. Toulouse: L.B.E.V., Lome \& L.E.T.

Aguirre-Gutiérrez J, Seijmonsbergen A C, Duivenvoorden J F, 2012. Optimizing land cover classification accuracy for change detection, a combined pixel-based and object-based approach in a mountainous area in Mexico. Applied Geography, 34: 29-37.

Badjana H M, Selsam P, Wala K et al., 2014. Assessment of land-cover changes in a sub-catchment of the Oti basin (West Africa): A case study of the Kara River basin. Zbl. Geol. Paläont. Teil I, Jg, 1: 151-170.

Balthazar V, Vanacker V, Molina A et al., 2015. Impacts of forest cover change on ecosystem services in high Andean mountains. Ecological Indicators, 48: 63-75.

Bicheron P, Defourny P, Brockmann C et al., 2008. GLOBCOVER: Products Description and Validation Report. In: PROJECT G (ed.). MEDIAS-France/POSTEL.

Biro K, Pradhan B, Buchroithner M et al., 2013. Land use/land cover change analysis and its impact on soil properties in the northern part of Gadarif Region, Sudan. Land Degradation \& Development, 24: 90-102.

Braimoh A K, 2004. Modeling land-use change in the Volta Basin of Ghana.

Braimoh A K, Vlek P L G, 2004. Land-cover change analyses in the Volta Basin of Ghana. Earth Interactions, 8: $1-17$.

Braimoh A K, Vlek P L G, 2005. Land-cover change trajectories in Northern Ghana. Environmental Management, 36: $356-373$.

Carmona A, Nahuelhual L, 2012. Combining land transitions and trajectories in assessing forest cover change. Applied Geography, 32: 904-915.

Castro A J, Martín-López B, López E et al., 2015. Do protected areas networks ensure the supply of ecosystem services? Spatial patterns of two nature reserve systems in semi-arid Spain. Applied Geography, 60: 1-9.

Damnyag L, Saastamoinen O, Blay D et al., 2013. Sustaining protected areas: Identifying and controlling deforestation and forest degradation drivers in the Ankasa Conservation Area, Ghana. Biological Conservation, 165 , 86-94.

DGSCN 2010. Recensement general de la population et de l'habitat. Resultats definitifs. Lome: Togo.

Diallo Y, Hu G, Wen X, 2010. Assessment of land use cover changes using NDVI and DEM in Puer and Simao counties, Yunnan Province, China. Report and Opinion, 2: 7-16.

Dourma M, Wala K, Bellefontaine R et al., 2009. Comparaison de l'utilisation des ressources forestières et de la régénération entre deux types de forêts claires à Isoberlinia au Togo. Bois et Forets des Tropiques, 302: 5-19.

Ellis C E, 2011. Anthropogenic transformation of the terrestrial biosphere. Phil. Trans. R. Soc A, 369: 1010-1035.

Ellis C E, Fuller D Q, Kaplan et al., 2013. Dating the Anthropocene: Towards an empirical global history of human transformation of the terrestrial biosphere. Elementa: Science of the Anthropocene, 18(1): 1-6.

Ellis E C, 2013. Sustaining biodiversity and people in the world's anthropogenic biomes. Current Opinion in Environmental Sustainability, 5: 368-372.

Ern H, 1979. Die Vegetation Togos, Gliederung, Gefährdung, Erhaltung. Willdenowia, 9: 295-315.

Fan Z, Zhang X, Li J et al., 2013. Land-cover changes of national nature reserves in China. Journal of Geographical Sciences, 23(2): 258-270.

FAO, 1996. Forest Resources Assessment. Survey of Tropical Forest Cover and Study of Change Processes. Rome, Italy, 1990.

FAO, 2015. Global Forest Resource Assessment 2015. How are the world's forests changing? Rome, Italy.

Farooq A, 2012. Detection of change in vegetation cover using multi-spectral and multi-temporal information for District Sargodha, Pakistan. Soc. \& Nat., Uberlândia, 24: 557-572.

Folega F, Wala K, Zhang C et al., 2011. Woody vegetation of protected areas in northern Togo. Cases of Barkoissi, Galangashi and Oti-Keran: Ecological and structure analyses of plant communities. For. Stud. China, 13: 23-35.

Folega F, Woegan Y A, Dourma M et al., 2015. Long term evaluation of green vegetation cover dynamic in the Atacora Mountain Chain (Togo) and its Relation to Carbon Sequuestration in West Africa. J. Mt. Sci., 12: 921-934.

Folega F, Zhang C, Woegan Y A et al., 2014a. Structure and ecology of forest plant community in Togo. Journal of Tropical Forest Science, 26: 225-239.

Folega F, Zhang C, Zhao X et al., 2014b. Satellite monitoring of land-use and land-cover changes in northern Togo protected areas. Journal of Forestry Research, 25: 385-392.

Fontodji K J, Atsri H, Adjonou K et al., 2011. Impact of charcoal production on biodiversity in Togo (West Africa). In: (ED.), D. J. L.-P. (ed.). The Importance of Biological Interactions in the Study of Biodiversity. In- 
Tech.

Gaia V, 2011. An epoch debate. Science, 334: 32-37.

Garedew E, 2010. Land-use and land-cover dynamics and rural livelihood perspectives, in the semi-arid areas of Central Rift Valley of Ethiopia [D]. Swedish University of Agricultural Sciences.

Griffiths P, Kuemmerle T, Kennedy R et al., 2012. Using annual time-series of Landsat images to assess the effects of forest restitution in post-socialist Romania. Remote Sensing of Environment, 118: 199-214.

Gutiérrez Angonese J, Grau H R, 2014. Assessment of swaps and persistence in land cover changes in a subtropical periurban region, NW Argentina. Landscape and Urban Planning, 127: 83-93.

He J, Lang R, Xu J, 2014. Local dynamics driving forest transition: Insights from upland villages in Southwest China. Forests, 5: 214-233.

Houet T, Verburg P H, Loveland T R, 2010. Monitoring and modelling landscape dynamics. Landscape Ecology, 25: $163-167$.

IGN, 1986. Cartes topographiques 1/200 000, 1 res Editions, Feuilles Sokode et Kara. France and D.C. N. C. \& M.E.M.P.T., Togo.

Jiang J, Zhou J, Wu H et al., 2005. Land cover changes in the rural-urban interaction of Xi'an region using Landsat TM/ETM data. Journal of Geographical Sciences, 15(5): 423-430.

Kang N, Sakamoto T, Imanishi J et al., 2013. Characterizing the historical changes in land use and landscape spatial pattern on the oguraike floodplain after the Meiji Period. Intercultural Understanding, 3: 11-16.

Kennedy R E, Townsend P A, Gross J E et al., 2009. Remote sensing change detection tools for natural resource managers: Understanding concepts and tradeoffs in the design of landscape monitoring projects. Remote Sensing of Environment, 113: 1382-1396.

Kim I, Le Q B, Park S et al., 2014. Driving forces in archetypical land-use changes in a mountainous watershed in East Asia. Land, 3: 957-980.

Kokou K, Nuto Y, Atsri H, 2009. Impact of charcoal production on woody plant species in West Africa: A case study in Togo. Scientific Research and Essay, 4: 881-893.

Lambin E F, Geist H J, Lepers E, 2003. Dynamics of land use and land cover change in tropical regions. Annu. Rev. Environ. Resour., 28: 205-241.

Le Q B, Tamene L, Vlek P L G, 2012. Multi-pronged assessment of land degradation in West Africa to assess the importance of atmospheric fertilization in masking the processes involved. Global and Planetary Change, 92/93: 71-81.

Leh M, Bajwa S, Chaubey I, 2013. Impact of land use change on erosion risk: An integrated remote sensing, geographic information system and modeling methodology. Land Degradation \& Development, 24: 409-421.

Lindstrom S, Mattson E, Nissanka S P, 2012. Forest cover change in Sri Lanka: The role of small scale farmers. Applied Geography, 34: 680-692.

Lu D, 2006. The potential and challenge of remote sensing-based biomass estimation. International Journal of Remote Sensing, 27: 1297-1328.

Lung T, Schaab G, 2010. A comparative assessment of land cover dynamics of three protected forest areas in tropical eastern Africa. Environmental Monitoring and Assessment, 61: 531-548.

Mander Ü, Uuemaa E, 2010. Landscape assessment for sustainable planning. Ecological Indicators, 10: 1-3.

Matsushita B, Yang W, Chen J et al., 2007. Sensitivity of the Enhanced Vegetation Index (EVI) and Normalized Difference Vegetation Index (NDVI) to topographic effects: A case study in high-density cypress forest. Sensors, 7: 2636-2651.

Mattsson E, Persson U M, Ostwald M et al., 2012. REDD+ readiness implications for Sri Lanka in terms of reducing deforestation. Journal of Environmental Management, 100, 29-40.

Mbow C, Smith P, Skole D et al., 2014a. Achieving mitigation and adaptation to climate change through sustainable agroforestry practices in Africa. Current Opinion in Environmental Sustainability, 6: 8-14.

Mbow C, Van Noodwijk M, Prabhu R et al., 2014b. Knowledge gaps and research needs concerning agroforestry's contribution to Sustainable Development Goals in Africa. Current Opinion in Environmental Sustainability, 6: 162-170.

McGarigal K, Cushman S A, Neel M C et al., 2002. Fragstats: Spatial pattern analysis program for categorical maps, Amherst, USA, University of Massachusetts.

McGarigal K, Marks B J, 1995. FRAGSTATS: Spatial pattern analysis program for quantifying landscape structure, Corvallis, Oregon, Forest Science Department Oregon State University.

MEA 2005. Ecosystems and human well-being: Synthesis. Washington, DC: Island Press. 
Monserud R A, Leemans R, 1992. Comparing global vegetation maps with the Kappa statistic. Ecological Modelling, 62: 275-293.

Nakakaawa C A, Vedeld P O, Aune J B, 2010. Spatial and temporal land use and carbon stock changes in Uganda: Implications for a future REDD strategy. Mitigation and Adaptation Strategies for Global Change, 16: $25-62$.

Nolte C, Agrawal A, Silvius K M et al., 2013. Governance regime and location influence avoided deforestation success of protected areas in the Brazilian Amazon. Proc. Natl. Acad. Sci. USA, 110: 4956-4961.

Ouedraogo I, 2010. Land use dynamics and demographic change in southern Burkina Faso. Acta Universitatis Agriculturae Sueciae.

Pang A, Li C, Wang X., 2010. Land use/cover change in response to driving forces of Zoige County, China. Procedia Environmental Sciences, 2: 1074-1082.

Pang C, Yu H, He J, 2013. Deforestation and changes in landscape patterns from 1979 to 2006 in Suan County, DPR Korea. Forests, 4: 968-983.

Pattanaik C, Reddy C S, Reddy P M, 2011. Assessment of spatial and temporal dynamics of tropical forest cover: A case study in Malkangiri district of Orissa, India. Journal of Geographical Sciences, 21(1): 176-192.

Paudel N S, Vedeld P O, Khatri D B, 2015. Prospects and challenges of tenure and forest governance reform in the context of REDD+ initiatives in Nepal. Forest Policy and Economics, 52: 1-8.

Peng J, Wang Y, Zhang Y et al., 2010. Evaluating the effectiveness of landscape metrics in quantifying spatial patterns. Ecological Indicators, 10: 217-223.

Petursson J G, Vedeld P, Sassen M, 2013. An institutional analysis of deforestation processes in protected areas: The case of the transboundary Mt. Elgon, Uganda and Kenya. Forest Policy and Economics, 26: 22-33.

Pontius J R G, Shusas E, Mceachern M, 2004. Detecting important categorical land changes while accounting for persistence. Agriculture, Ecosystems and Environment, 101: 251-268.

Porter-Bolland L, Ellis E A, Guariguata M R et al., 2012. Community managed forests and forest protected areas: An assessment of their conservation effectiveness across the tropics. Forest Ecology and Management, 268: $6-17$.

Portillo-Quintero C A, Sanchez A M, Valbuena C A et al., 2012. Forest cover and deforestation patterns in the Northern Andes (Lake Maracaibo Basin): A synoptic assessment using MODIS and Landsat imagery. Applied Geography, 35: 152-163.

Renetzeder C, Schindler S Peterseil J et al., 2010. Can we measure ecological sustainability? Landscape pattern as an indicator for naturalness and land use intensity at regional, national and European level. Ecological Indicators, 10: 39-48.

Rogan J, Chen D, 2004. Remote sensing technology for mapping and monitoring land-cover and land-use change. Progress in Planning, 61: 301-321.

Rojas C, Pino J, Basnou C et al., 2013. Assessing land-use and -cover changes in relation to geographic factors and urban planning in the metropolitan area of Concepción (Chile). Implications for biodiversity conservation. Applied Geography, 39: 93-103.

Romero-Ruiz M H, Flantua S G A, Tansey K et al., 2012. Landscape transformations in savannas of northern South America: Land use/cover changes since 1987 in the Llanos Orientales of Colombia. Applied Geography, 32: 766-776.

Ruelland D, Levavasseur F, Tribotté A, 2010. Patterns and dynamics of land-cover changes since the 1960s over three experimental areas in Mali. International Journal of Applied Earth Observation and Geoinformation, 12: $11-17$.

Schindler S, Von Wehrden H, Poirazidis K et al., 2013. Multiscale performance of landscape metrics as indicators of species richness of plants, insects and vertebrates. Ecological Indicators, 31: 41-48.

Schleuning M, Farwig N, Peters M K et al., 2011. Forest fragmentation and selective logging have inconsistent effects on multiple animal-mediated ecosystem processes in a tropical forest. PLoS One, 6: e27785.

Schmitt-Harsh M, 2013. Landscape change in Guatemala: Driving forces of forest and coffee agroforest expansion and contraction from 1990 to 2010. Applied Geography, 40: 40-50.

Specht M J, Pinto S R R, Albuqueque U P et al., 2015. Burning biodiversity: Fuelwood harvesting causes forest degradation in human-dominated tropical landscapes. Global Ecology and Conservation, 3: 200-209.

Teferi E, Bewket W, Uhlenbrook S et al., 2013. Understanding recent land use and land cover dynamics in the source region of the Upper Blue Nile, Ethiopia: Spatially explicit statistical modeling of systematic transitions. Agriculture, Ecosystems \& Environment, 165: 98-117. 
Tfwala S S, Manyatsi A M, Wang Y, 2012. Assessment of land degradation at Velezizweni, Swaziland. Research Journal of Environmental and Earth Sciences, 4: 878-883.

Traoré L, Sop T K, Dayamba S D et al., 2012. Do protected areas really work to conserve species? A case study of three vulnerable woody species in the Sudanian zone of Burkina Faso. Environment, Development and Sustainability, 15: 663-686.

Traore S S, Forkuo E K, Traore C S P et al., 2015. Assessing the inter-relationship between vegetation productivity, rainfall, population and land cover over the Bani River Basin in Mali (West Africa). IOSR Journal of Engineering, 5: 10-18.

Traore S S, Landmann T, Forkuo E K et al., 2014. Assessing long term trends in vegetation productivity change over the Bani River Basin in Mali (West Africa). Journal of Geography and Earth Sciences, 2: 21-34.

Tumusiime D M, Vedeld P, Gombya-Ssembajjwe W, 2011. Breaking the law? Illegal livelihoods from a protected area in Uganda. Forest Policy and Economics, 13: 273-283.

Uuemaa E, Mander Ü, Marja R, 2013. Trends in the use of landscape spatial metrics as landscape indicators: A review. Ecological Indicators, 28: 100-106.

Vedeld P, Jumane A, Wapalila G et al., 2012. Protected areas, poverty and conflicts. Forest Policy and Economics, 21: 20-31.

Verburg P H, Van Asselen S, Van Der Zanden et al., 2013. The representation of landscapes in global scale assessments of environmental change. Landscape Ecology, 28: 1067-1080.

Vu Q M, Le Q B, Vlek P L G, 2014. Hotspots of human-induced biomass productivity decline and their social-ecological types toward supporting national policy and local studies on combating land degradation. Global and Planetary Change, 121: 64-77.

Waiswa D, 2011. Dynamics of forest cover extent, forest fragmentation and their drivers in the Lake Victoria crescent, Uganda from 1989 to 2009 [D]. Virginia Polytechnic Institute and State University.

Wala K, Woegan Y A, Borozi W et al., 2012. Assessment of vegetation structure and human impacts in the protected area of Aledjo (Togo). African Journal of Ecology, 50: 355-366.

Walz U, 2011. Landscape structure, landscape metrics and biodiversity. Living Rev. Landscape Res., 5: 5-16.

Wang D, Gong J, Chen L et al., 2013. Comparative analysis of land use/cover change trajectories and their driving forces in two small watersheds in the western Loess Plateau of China. International Journal of Applied Earth Observation and Geoinformation, 21: 241-252.

Weng Y-C, 2007. Spatiotemporal changes of landscape pattern in response to urbanization. Landscape and Urban Planning, 81: 341-353.

Were K O, Dick Q B, Singh B R, 2013. Remotely sensing the spatial and temporal land cover changes in Eastern Mau forest reserve and Lake Nakuru drainage basin, Kenya. Applied Geography, 41: 75-86.

White J, Shao Y, Kennedy L et al., 2013. Landscape Dynamics on the Island of La Gonave, Haiti, 1990-2010. Land, 2: 493-507.

Wilson H E, Sader S A, 2002. Detection of forest harvest type using multiple dates of Landsat TM imagery. Remote Sensing of Environment, 80: 385-396.

Wittig R, Konig K, Schmidt M et al., 2007. A study of climate change and anthropogenic impacts in West Africa. Env. Sci. Pollut. Res., 14: 182-189.

Woegan Y A, 2007. Diversite des formations végétales de deux aires protégées de l'Atakora Nord : la réserve de faune d'Alédjo et Malfakassa [D]. University of Lome.

Wu C-F, Lin Y-P, Chiang L-C et al., 2014. Assessing highway's impacts on landscape patterns and ecosystem services: A case study in Puli Township, Taiwan. Landscape and Urban Planning, 128: 60-71.

Zhai D L, Cannon C H, Dai Z C et al., 2015. Deforestation and fragmentation of natural forests in the upper Changhua watershed, Hainan, China: Implications for biodiversity conservation. Environ. Monit. Assess., 187: 4137.

Zhang Z, Van Coillie F, De Clercq E M et al., 2013. Mountain vegetation change quantification using surface landscape metrics in Lancang watershed, China. Ecological Indicators, 31: 49-58.

Zheng B, Myint S W, Fan C, 2014. Spatial configuration of anthropogenic land cover impacts on urban warming. Landscape and Urban Planning, 130: 104-111.

Zhou Q, Li B, Kurban A, 2008. Trajectory analysis of land cover change in arid environment of China. Int. J. Remote Sensing, 29: 1093-1107. 